\title{
New species, new records, and taxonomical notes in Cerambycidae (Coleoptera) from the state of Espírito Santo (Brazil)
}

\author{
1 Universidade de São Paulo (USP), Museu de Zoologia (MZUSP). São Paulo, SP, Brasil. \\ ${ }^{2}$ Instituto Capixaba de Pesquisa, Assistência Técnica e Extensão Rural (INCAPER). Vitória, ES, Brasil. \\ ORCID: http://orcid.org/0000-0002-8465-3134.E-mail: davidmartins@incaper.es.gov.br \\ ${ }^{3}$ ORCID: http://orcid.org/0000-0001-7128-1418. E-mail: toncriss@uol.com.br \\ ${ }^{4}$ ORCID: http://orcid.org/0000-0002-5547-7987.E-mail:jp_bot@yahoo.com \\ 5 ORCID: http://orcid.org/0000-0002-5047-8921. E-mail: eribnascimentofl@gmail.com
}

Antonio Santos-Silva ${ }^{1,3}$; Juan Pablo Botero ${ }^{1,4}$; Francisco Eriberto de Lima Nascimento ${ }^{1,5}$ \& David dos Santos Martins ${ }^{2}$

\begin{abstract}
Twenty three new state records of Cerambycidae are provided for Espírito Santo State, Brazil. Forgotten geographical records for Desmiphora (Desmiphora) cirrosa Erichson, 1847, and Cipriscola fasciata (Thomson, 1860) are mentioned. Notes on Metacriodion capixaba Fragoso, 1970, Potiaete maculata Martins \& Galileo, 1999, and Eriphus mexicanus Audinet-Serville, 1834 are presented. The female of Trestonia grisea Martins \& Galileo, 1990 is described for the first time. Stenoeme annularis Martins, 1980 is redescribed and a key to species of Stenoeme is provided. Four new species are described from the Brazilian state of Espírito Santo: Microibidion fiuzai, Iquiracetima venturai, Adesmus culiki, and Xenofrea simplicioi.
\end{abstract}

Key-Words. Longhorned beetles; Neotropical region; South America; Taxonomy.

\section{INTRODUCTION}

The state of Espírito Santo, located in southeastern Brazil (Fig. 1), has all of its territory covered by the Atlantic Forest domains, one of the most biodiverse and threatened biome on the planet (Brown \& Gibson, 1983). Despite maintaining only $8.85 \%$ of its territory with its original vegetal coverage, the state contains several preserved fragments of Atlantic Forest, with distinct vegetation formations determined mainly by geological and edaphoclimatic factors (Garay et al., 2004; Peixoto et al., 2008). This vegetational heterogeneity has resulted in the formation of several ecosystems conducive to the development of a great wealth of insect species.

Cerambycidae, one of the most diverse Coleoptera families, are very common in forest ecosystems where they play important roles in maintaining and evolving ecological processes through numerous natural mechanisms (Didhamet et al., 1996; Tavakilian et al., 1997). Among the Brazilian states, Espírito Santo stands out with a diverse fauna of Cerambycidae (Monné, 2020a, b, c), with the majority collected in the northern region of the state, mainly in the Sooretama Biological Reserve (Travassos \& Freitas, 1948; Zajciw, 1974), which is the largest protected area in the Espírito Santo and the oldest reserve in Brazil (Sarmento-Soares \& Martins-Pinheiro, 2014).

Although our knowledge is still incipient in other regions of the state, there are some areas where the entomofauna has been collected for several years, with different capture methods, and specimens of longhorned beetles have been incorporated and maintained in scientific entomological collections of institutions/companies, such as: Reserva Natural Vale; Suzano S.A.; Instituto Capixaba de Pesquisa, Assistência Técnica e Extensão Rural (Incaper), and Universidade Federal do Espírito Santo. In this study, we present new species of Cerambycidae and new records of occurrence in the state of Espírito Santo.

\section{MATERIAL AND METHODS}

The acronyms used in the text are as follows: BMNH = The Natural History Museum, London, United Kingdom; FSCA = Florida State Collection of Arthropods, Gainesville, Florida, United States of America; MNRJ = Museu Nacional, Universidade Federal do Rio de Janeiro, Rio de Janeiro, Rio de Janeiro, Brazil; MZSP = Museu de Zoologia, Universidade de São Paulo, São Paulo, 
Brazil; RNV = Reserva Natural Vale, Linhares, Espírito Santo, Brazil; SSA = Suzano S.A., Aracruz, Espírito Santo, Brazil; UFES = Universidade Federal do Espírito Santo, Vitória, Espírito Santo, Brazil.

The collection of the RNV was created in 1986 and consists only of insects collected within approximately 22,000 hectares of preserved vegetation in the domain of the Perennial Forest (Jesus \& Rolim, 2005; Martins et al., 2014; Martins et al., 2016). The Reserve, intended for conservation, scientific research, and ecological tourism, is considered one of the centers of high diversity and endemism in Brazil, and also one of the best protected conservation areas in South America (Kierulff et al., 2014).

The SSA entomological collection is a reference for the company's forestry activities in the region. It is located in the municipality of Aracruz, on the northern coast of the state, where it was started in the 1970s with insects collected near fragments of natural forest vegetation maintained as refuges in the company's eucalyptus cultivation areas. Most of the Cerambycidae in the collection were collected in the area called Microbasin I, which from 2007 onwards was incorporated into the Indigenous Reserve of the Tupiniquim and Guarani ethnic groups living in that municipality.

The collections of UFES and Incaper have specimens of longhorned beetles collected in different areas and environments of the state, including some Environmental Conservation Units of Atlantic Forest vegetation, such as: National Forest of Goytacazes and Reserva Natural Vale, both in Linhares; Sooretama Biological Reserve, in Sooretama; and Santa Lúcia Biological Station, in the municipality of Santa Teresa. All specimens from those entomological collections were identified at the Zoology
Museum of São Paulo, as an activity of a larger project "Biomes of Brazil: Atlantic Forest", to advance the knowledge of "Entomofauna in the state of Espírito Santo".

Photographs were taken in the MZSP with a Canon EOS Rebel T3i DSLR camera, Canon MP-E 65mm f/2.8 1-5X macro lens, controlled by Zerene Stacker AutoMontage software. The map was made through Esri ArcGIS software, version 10.5 (Environmental Systems Research Institute, 2017). Measurements were taken in " $\mathrm{mm}$ " using measuring ocular Hensoldt/Wetzlar - Mess 10 in the Leica MZ6 stereomicroscope, also used in the study of the specimens.

The references on known species (only species described or redescribed) are restricted to the original description and Monné's catalog (2020a, b, c).

\section{RESULTS}

\section{New Records \\ Prioninae Latreille, 1802 \\ Callipogonini Thomson, 1861 \\ Enoplocerus armillatus (Linnaeus, 1767)}

Material examined: BRAZIL, Espírito Santo (new state record): Vila Velha (20¹9'46.9"S, 40¹7'33.0"W), 1 specimen, 20.VII.2001, D.C. Tomasi (UFES).

This species was originally described from "India". We believe that Linnaeus (1767) did not examine any specimen himself. The description provided by him indicates he was only naming the species described by Gronovius (1764), and illustrated by Gronovius (1781). Furthermore, Grovonius (1764) also reported that the species "Habitat in India". It seems almost impossible that both Linnaeus

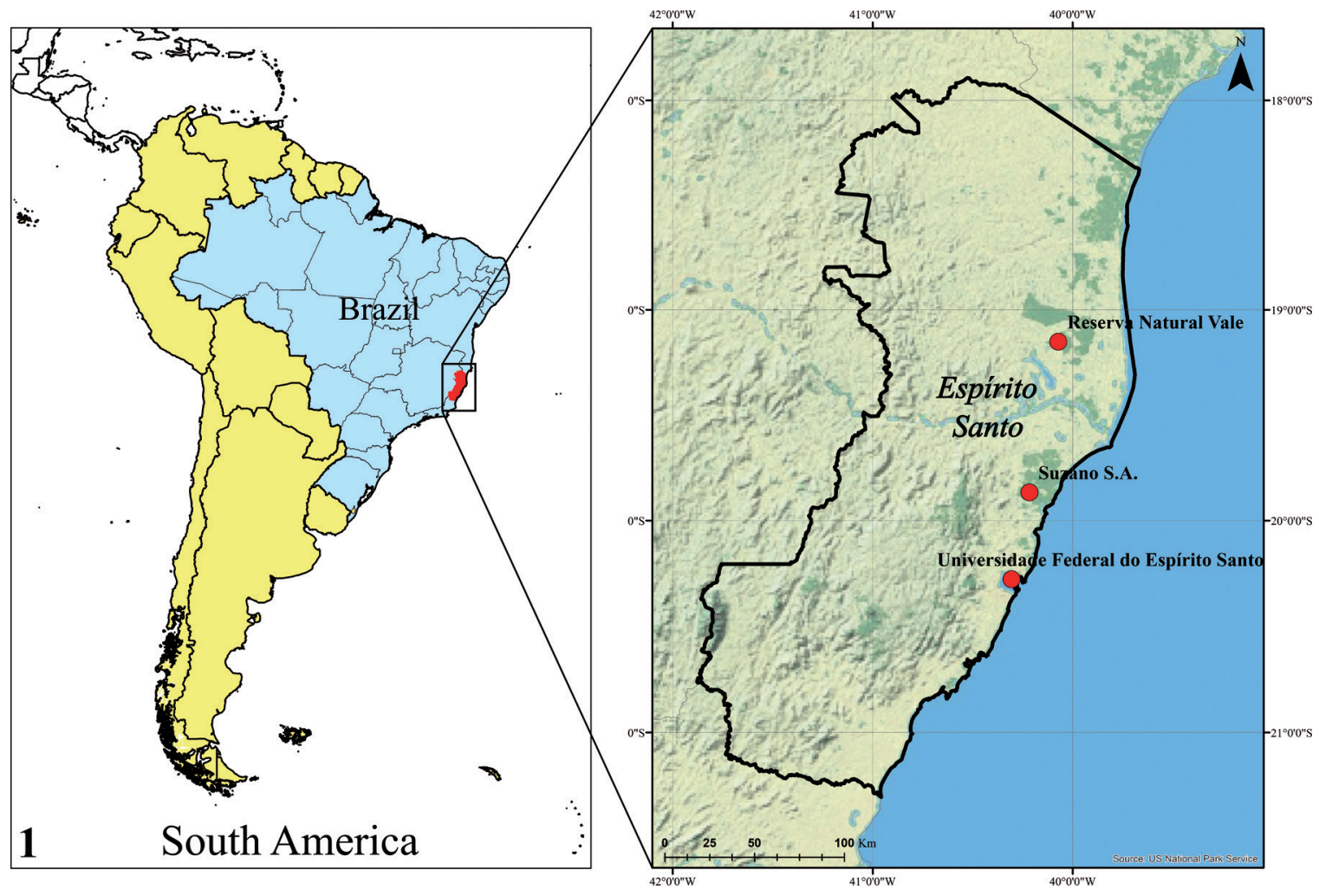

Figure 1. Map showing the location of the state of Espírito Santo and institutions with entomological collections. 
and Gronovius have examined two specimens with the same error of origin, except if Linnaeus had examined the specimen in the Gronovius collection, but there is no evidence that this has occurred. Still, even if the latter hypothesis is true, it would only indicate that the specimen belonged to the Gronovius collection. Unfortunately, Gronovius' collection has disappeared and it is unknown if his specimens are still preserved. Currently, the species is recorded for Costa Rica, Trinidad \& Tobago, Panama, Colombia, Venezuela, Surinam, Guyana, French Guiana, Brazil (Amazonas, Pará, Roraima, Rondônia, Mato Grosso, Goiás, Maranhão, Rio Grande do Norte, Paraíba, Alagoas, Bahia, Rio de Janeiro, São Paulo, Paraná), Ecuador, Peru, Bolivia (Beni, Pando, Santa Cruz), Paraguay, Argentina (Salta, Tucumán, Santiago del Estero, Misiones, Chaco, Santa Fé) (Monné, 2020c).

\section{Cerambycinae Latreille, 1802 \\ Cerambycini Latreille, 1802 \\ Sphallotrichina Martins \& Monné, 2002 Xestiodion similis (Melzer, 1920)}

Material examined: BRAZIL, Espírito Santo (new state record): Aracruz, $19^{\circ} 52^{\prime} 03^{\prime \prime} \mathrm{S}, 40^{\circ} 12^{\prime} 55^{\prime \prime} \mathrm{W}, 1$ specimen, 04.IX.1984, P.M. Vieira col. (SSA).

This species was originally described from Brazil (São Paulo, Amazonas). Fragoso (1981) questioned the accuracy of the origin of the specimen from the Brazilian state of Amazonas. Currently, it is known from Brazil (Minas Gerais, São Paulo) (Monné, 2020a).

\section{Clytini Mulsant, 1839 \\ Pirangoclytus insignis (Chevrolat, 1862)}

(Fig. 2)

Material examined: BRAZIL, Espírito Santo (new state record): Aracruz, 1947'59"S, 4012'52"W, 1 \%, 18.VI.1993, J.B. da Silva col. (SSA); Aracruz, $19^{\circ} 48^{\prime} 07^{\prime \prime} S, 40^{\circ} 07^{\prime} 58^{\prime \prime} \mathrm{W}$, 1 \&, 14.X.1993, P.M. Vieira col. (SSA); Aracruz, 1953'27"S, 40¹1'07"W, 1 \%, 14.X.1993, J.F. Ramos col. (SSA); Aracruz, $19^{\circ} 51^{\prime} 32^{\prime \prime} \mathrm{S}, 40^{\circ} 13^{\prime} 15^{\prime \prime} \mathrm{W}, 1$ \&, W.L. Selvatici col. (SSA); Aracruz, 1 , no date and collector indicated (SSA).

This species was described from Brazil (no further details). Currently, it is known from Brazil (Minas Gerais, São Paulo, Paraná, Santa Catarina), Argentina (Misiones) (Monné, 2020a). According to Martins \& Galileo (2011), Viana (1972) recorded the species from Paraguay (translated): "VIANA (1972: 307) marked it, still under the name of Mecometopus palmatus, for Paraguay, Alto Paraná: Puerto Bertoni; San Pedro: San Pedro".

\section{Eburiini Blanchard, 1845 Pantomallus tristis (Blanchard, 1847)}

Material examined: BRAZIL, Espírito Santo (new state record): Linhares, $19^{\circ} 08^{\prime} 52.8^{\prime \prime} \mathrm{S}, 40^{\circ} 04^{\prime} 03.2^{\prime \prime} \mathrm{W}, 1$ specimen, 11.XII.1987, J.S. Santos col. (RNV); Linhares, $19^{\circ} 09^{\prime} 34.4^{\prime \prime}$,
4002'17.3"W, 1 specimen, 22.I.1988, J.S. Santos col. (RNV); Linhares, $19^{\circ} 08^{\prime} 52.8^{\prime \prime} \mathrm{S}, 40^{\circ} 04^{\prime} 03.2^{\prime \prime} \mathrm{W}, 1$ specimen, 11.XII.1990, J.S. Santos col. (RNV).

This species was originally described from Bolivia. Currently, it is known from Bolivia (Santa Cruz), Brazil (Pará, Rondônia, Mato Grosso, Maranhão) (Monné, 2020a). Martins (1997a) also reported it from Peru.

\section{Phoracanthini Newman, 1840 Phoracantha recurva Newman, 1840} (Fig. 3)

Material examined: BRAZIL, Espírito Santo (new state record): Linhares, $1 \sigma^{\circ}, 03$. VII.2010, J.S. Santos col. (RNV).

This species was described from New Holland (Australia). Currently it is known in America from the United States (California), Brazil (Bahia, Minas Gerais, Paraná, Santa Catarina, Rio Grande do Sul), Paraguay, Chile, Argentina (Corrientes, Córdoba, La Rioja, Santa Fé, Entre Ríos, Buenos Aires, La Pampa, Río Negro), Uruguay (Monné, 2020a).

\section{Trachyderini Dupont, 1836 Ancylocerina Thomson, 1864 Ceralocyna nigricollis (Gounelle, 1911)}

Material examined: BRAZIL, Espírito Santo (new state record): Aracruz, 19 $51^{\prime} 32^{\prime \prime} \mathrm{S}, 40^{\circ} 13^{\prime} 05^{\prime \prime} \mathrm{W}, 1$ \% , 22.V.1995, J.A.C. Simões col. (MZSP); Linhares, 1 o", XI.1972, P.C. Elias col. (MZSP). Minas Gerais (new state record): Belo Horizonte, 1 , no additional data (MZSP).

This species was described from Brazil (Goiás). Currently, it is known from Brazil (Mato Grosso, Goiás), Bolivia (Santa Cruz) (Monné, 2020a). The species shows some chromatic variation: sides of pronotum orange or red; elytra mostly orange or red; prosternum entirely orange or with anterior area black; femora may be entirely black or meso- and metafemora bicolorous (basal third yellowish brown or reddish brown and remaining surface black).

Gounelle (1911) described C. terminata var. nigricollis based on males and females. Monné \& Giesbert (1992) considered this subspecies as distinct from C. terminata. Comparing photographs of the holotype of C. terminata with that of a syntype of $C$. nigricollis, as well as with the specimens examined by us, $C$. nigricollis differs from C. terminata only by the elytral punctures not aligned in rows, while they are aligned in the latter.

\section{Lamiinae Latreille, 1825 Acanthocinini Blanchard, 1845 Lasiolepturges zikani Melzer, 1928} (Fig. 4)

Material examined: BRAZIL, Espírito Santo (new state record): Aracruz, 1949'20"S, 4008'16"W, 1 o', 30.IV.1986, P.M. Vieira col. (SSA). 
This species was described from Brazil (Rio de Janeiro). Currently, it is known from Brazil (Rio de Janeiro, São Paulo, Santa Catarina), Peru, Bolivia (Santa Cruz), French Guiana (Monné, 2020b). Schmid (2017), based on Bezark \& Monné (2013), listed it in Ecuador.

\section{Lophopoeum meridianum Fisher, 1938}

(Fig. 5)

Material examined: BRAZIL, Espírito Santo (new state record): Aracruz, 1952'01"S, 40¹2'37"W, 1 o', 20.V.1995, J.A.C. Simões col. (SSA).

This species was described from Brazil (Santa Catarina). Currently, it is only known from Brazil (Minas Gerais, Rio de Janeiro, São Paulo, Santa Catarina) (Monné, 2020b).

\section{Acanthoderini Thomson, 1860 Cotycicuiara chionea Martins \& Galileo, 2010}

(Fig. 6)

Material examined: BRAZIL, Espírito Santo (new state record): Sooretama, Fazenda Cupido e Refúgio, 1903'44"S, $39^{\circ} 58^{\prime} 36^{\prime \prime} \mathrm{W}, 10^{\circ}, 16 . X I .2015$, M.T. Tavares \& S. Freitas col. (UFES).

This species was described from Brazil (Minas Gerais, Rio de Janeiro, Paraná). Currently it is also known from the Brazilian state of Paraná (Monné, 2020b).

\section{Cotycicuiara pertusa Martins \& Galileo, 2010}

(Fig. 7)

Material examined: BRAZIL, Espírito Santo (new state record): Aracruz, $19^{\circ} 52^{\prime} 02^{\prime \prime} \mathrm{S}, 40^{\circ} 11^{\prime} 51^{\prime \prime} \mathrm{W}, 10^{\prime \prime}$, J.B. Silva col.

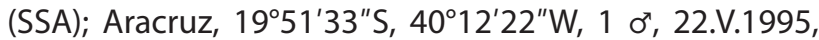
J.A.C. Simões col. (SSA).

This species was described and remains known only from Brazil (Rio de Janeiro, Santa Catarina) (Monné, 2020b).

\section{Zikanita perpulchra Lane, 1943}

(Fig. 8)

Material examined: BRAZIL, Espírito Santo (new state record): Linhares, Reserva Natural Vale, 1 \&, 16.XI.2016, Martins \& Fiuza col. (RNV).

This species was described from Brazil (Rio de Janeiro, São Paulo). Currently, it is known from Brazil (Bahia, Minas Gerais, Rio de Janeiro, São Paulo) (Monné, 2020b).

Acrocinini Swainson, 1840 Acrocinus longimanus (Linnaeus, 1758)

Material examined: BRAZIL, Espírito Santo (new state record): Aracruz, $19^{\circ} 51^{\prime} 12^{\prime \prime} \mathrm{S}, 40^{\circ} 12^{\prime} 27^{\prime \prime} \mathrm{W}, 1$ specimen,
24.VI.1987, P.M. Vieira col. (SSA); Aracruz, 1948'41"S, 4009'23"W, 1 specimen, 24.VI.1987, J.B. Silva col. (SSA); Aracruz, 1947'45"S, 4005'04"W, 1 specimen, 14.IX.1998, J.E.M. Alves col. (SSA); Linhares (Flona de Goytacazes), $19^{\circ} 26^{\prime} 10.5^{\prime \prime} \mathrm{S}, 40^{\circ} 04^{\prime} 24.3^{\prime \prime} \mathrm{W}, 1$ specimen, 22.XI.2017, D.S. Martins col. (RNV); Linhares (Reserva Natural Vale) $19^{\circ} 09^{\prime} 34.4^{\prime \prime} \mathrm{S}, 40^{\circ} 02^{\prime} 17.3^{\prime \prime} \mathrm{W}, 1$ specimen, 17.V.1998, J.S. Santos col. (RNV).

Linnaeus (1758) reported the species from America (no further details). However, he also listed the works by some previous authors: Grew (1681), who listed the species from "West-Indies"; Merian (1705), who listed the species from Surinam; Vincent (1699), who did not report any place; Rösel (1746), probably from Surinam. Accordingly, the type locality of the syntypes is "America", "West-Indies", and "Surinam", and not only "America" as has been reported in catalogs. Currently, it is known from Mexico (Jalisco, Veracruz, Chiapas), Belize, Guatemala, Honduras, El Salvador, Nicaragua, Costa Rica, Panama, Trinidad, Colombia, Venezuela, Ecuador, Surinam, French Guiana, Guiana, Brazil (Amazonas, Pará, Mato Grosso, Goiás, Bahia, Minas Gerais, Rio de Janeiro, São Paulo, Paraná, Rio Grande do Sul), Peru, Bolivia (Beni, La Paz, Santa Cruz), Paraguay, Argentina (Misiones, Corrientes) (Monné, 2020b).

\section{Apomecynini Thomson, 1860 \\ Adetus modestus Melzer, 1934}

(Fig. 9)

Material examined: BRAZIL, Espírito Santo (new state record): Aracruz, 1951'32"S, 40¹3'05"W, $10^{\prime \prime}, 22 . V .1995$, J.A.C. Simões col. (SSA).

This species was described from Brazil (São Paulo). Currently, it is known from Brazil (Rondônia, Mato Grosso, Mato Grosso do Sul, Goiás, Minas Gerais, Rio de Janeiro, São Paulo), Argentina (Santiago del Estero) (Monné, 2020b). Monné (1994b) reported the species from Rio Grande do Sul (Brazil).

\section{Falsischnolea nigrobasalis Breuning, 1940} (Fig. 10)

Material examined: BRAZIL, Espírito Santo (new state record): Aracruz, 1951'32"S, 40¹3'05"W, 1 \%, 22.V.1995, J.A.C. Simões col. (SSA).

This species was described and remains known only from Brazil (Rio de Janeiro) (Monné, 2020b).

\section{Desmiphorini Thomson, 1860}

\section{Blabicentrus lineatus Galileo \& Santos-Silva, 2016}

(Fig. 12)

Material examined: BRAZIL, Espírito Santo (new state record): Aracruz, 1951'47"S, 40¹2'12"W, 1 \%, 06.XI.1994, J.A.C. Simões (SSA). 

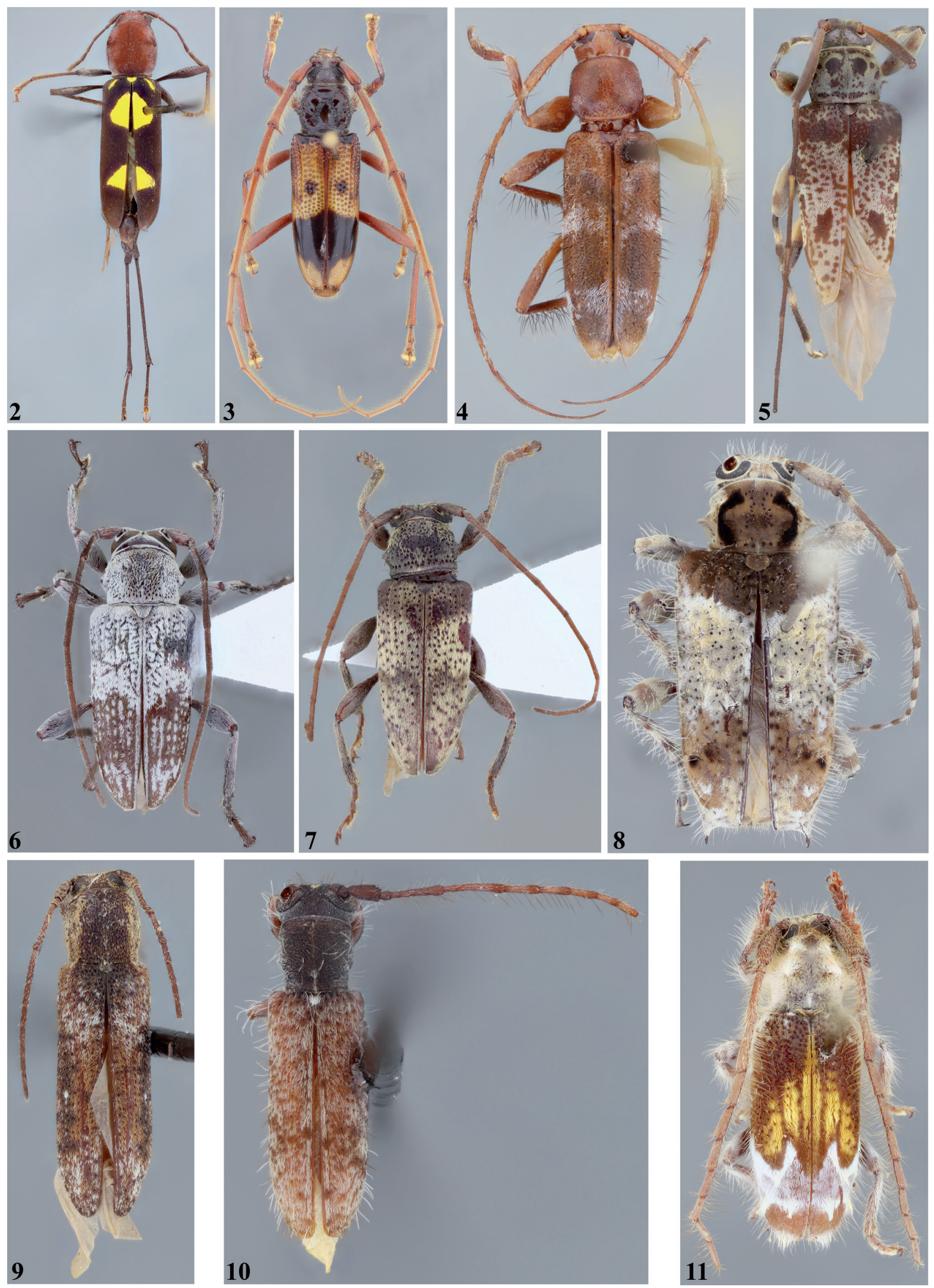

Figures 2-11. Dorsal habitus: (2) Pirangoclytus insignis, female; (3) Phoracantha recurva, male; (4) Lasiolepturges zikani, male; (5) Lophopoeum meridianum, male; (6) Cotycicuiara chionea, male; (7) Cotycicuiara pertusa, male; (8) Zikanita perpulchra, female; (9) Adetus modestus, male; (10) Falsischnolea nigrobasalis, female; (11) Desmiphora (Desmiphora) pretiosa, male. 
This species was recently described from Brazil (Rio de Janeiro) (Monné, 2020b). Unfortunately, the holotype was destroyed during a fire in the MNRJ.

\section{Desmiphora (Desmiphora) cirrosa Erichson, 1847} (Fig. 18)

Material examined:BRAZIL, Espírito Santo:Linhares, Reserva Natural Vale, 1 , 30.XI.2016, Martins \& Fiuza col. (RNV).

This species was described from Peru. Monné (2020b) listed it from Mexico (Nayarit, Veracruz, Tamaulipas, Quintana Roo, Jalisco, Chiapas), Guatemala, Honduras, Nicaragua, Costa Rica, Panama, Venezuela, French Guiana, Ecuador, Peru, Brazil (Amazonas, Ceará, Bahia, Minas Gerais, Espírito Santo, Rio de Janeiro, São Paulo, Paraná, Santa Catarina, Rio Grande do Sul), Bolivia (Santa Cruz, Tarija), Paraguay, Argentina (Tucumán, Formosa, Misiones), Uruguay. Zajciw (1965) also listed it in Paraíba (Brazil), a state record omitted in Monné (2020b).

\section{Desmiphora (Desmiphora) pretiosa Melzer, 1935} (Fig. 11)

Material examined: BRAZIL, Espírito Santo (new state record): Linhares, 1 ơ, 27.XII.1989, J.S.S. col. (RNV).

This species is currently known from Brazil (Goiás, Minas Gerais, São Paulo) (Monné, 2020b).

\section{Estola nigrosignata Breuning, 1940}

Material examined: BRAZIL, Espírito Santo (new state record): Aracruz, $19^{\circ} 48^{\prime} 55^{\prime \prime} \mathrm{S}, 40^{\circ} 09^{\prime} 42^{\prime \prime} \mathrm{W}, 1$ specimen, 22.V.1995, J.A.C. Simões col. (SSA).

This species is known only from Brazil (Minas Gerais) (Monné, 2020b).

\section{Pseudestola densepunctata Breuning, 1940} (Fig. 13)

Material examined: BRAZIL, Espírito Santo (new state record): Aracruz, 1951'51"S, 4008'14"W, 1 \%, 24.II.1988, M.P. Santos col. (SSA).

This species was described from Brazil (Rio de Janeiro). Currently, it is known from Brazil (Alagoas, Sergipe, Rio de Janeiro) and Bolivia (Santa Cruz) (Monné, 2020b).

Forsteriini Tippmann, 1960

\section{Proceroblesthis prolata Galileo \& Martins, 1987} (Fig. 14)

Material examined: BRAZIL, Espírito Santo (new state record): Aracruz, 1951'22"S, 4005'34"W, 1 ơ', 03.IX.1997, J.B. Silva col. (SSA).

This species was described and remains only known from Brazil (Minas Gerais) (Monné, 2020b).

\section{Hemilophini Thomson, 1868 \\ Butocrysa insignis (Lucas, 1857)}

(Fig. 15)

Material examined: BRAZIL, Espírito Santo (new state record): Linhares, 1 ơ, 09.XI.1990, J.S. Santos col. (RNV).

Butocrysa insignis was described from "Brésil intérieur" [inland Brazil], as Amphionycha insignis. It has been reported that the species was described based on a single specimen (holotype). However, Lucas (1857) indicated: "AMPHIONYCHA INSIGNIS (2)"; "(2) Dej. Cat. des Coléopt., $3^{e}$ edit., p. 379". Accordingly, the specimens from Pierre François Marie Auguste Dejean (currently in the BMNH) are syntypes. Apparently, Dejean was involved in the identification of the specimens because Lucas himself indicated this (translated): "By doing so, I hope to signal sufficiently the entomological riches gathered by the Scientific Commission of South America, under the skillful direction of M. Le Comte de Castelnau". Currently, it is known from Brazil (Minas Gerais, Rio de Janeiro, São Paulo) (Monné, 2020b).

\section{Phoebella albomaculata (Gahan, 1889)} (Fig. 16)

Material examined: BRAZIL, Espírito Santo (new state


M.P. Santos col. (SSA).

This species was described from Brazil (no further details). Currently, it is known from Brazil (Bahia) (Monné, 2020b).

\section{Onciderini Thomson, 1860 Cipriscola fasciata (Thomson, 1860)}

(Fig. 19)

Material examined: BRAZIL, Espírito Santo: Aracruz, $19^{\circ} 50^{\prime} 14^{\prime \prime} \mathrm{S}, 40^{\circ} 05^{\prime} 44^{\prime \prime} \mathrm{W}, 10^{\prime \prime}, 24 . \mathrm{VIII} .2006$, J.B. Silva col. (SSA); Aracruz, $19^{\circ} 48^{\prime} 35^{\prime \prime} \mathrm{S}, 40^{\circ} 05^{\prime} 42^{\prime \prime} \mathrm{W}, 10^{\prime \prime}, 03 . \mathrm{VI} .1984$, P.M. Vieira col. (SSA).

This species was described from Brazil (no further details). Currently, it is known from Colombia, Peru, Venezuela, Brazil (Pará, Mato Grosso, Mato Grosso do Sul, Maranhão, Pernambuco, Minas Gerais, Rio de Janeiro, São Paulo, Rio Grande do Sul), Peru, Bolivia (Santa Cruz, Tarija), Paraguay, Argentina (Misiones, Chaco, Corrientes) (Monné, 2020b). However, Zajciw (1974) recorded the species from the Brazilian state of Espírito Santo, and Menezes et al. (2012) listed it in the Brazilian state of Bahia, two state records omitted in Monné (2020b).

\section{Pteropliini Thomson, 1860} Rhaphiptera affinis Thomson, 1868

(Fig. 17)

Material examined: BRAZIL, Espírito Santo (new state record): Aracruz, $19^{\circ} 52^{\prime} 16^{\prime \prime} \mathrm{S}, 40^{\circ} 12^{\prime} 43^{\prime \prime} \mathrm{W}, 10^{\circ}$, 18.XII.2000, C.E. Scardua col. (SSA). 
This species was described from Brazil (no further details). Currently, it is known from Brazil (Bahia, Minas Gerais, Rio de Janeiro, São Paulo, Paraná, Santa Catarina, Rio Grande do Sul), Paraguay (Monné, 2020b).

\section{Rhaphiptera clarevestita Tippmann, 1953}

Material examined: BRAZIL, Espírito Santo (new state record): Linhares, 1 ơ, 01.XI.1988, J.S.S. col. (RNV); 1 \%, 20.II.1990, J.S. Santos col. (RNV).

This species was described from Brazil (São Paulo). Currently, it is known from Brazil (São Paulo, Santa Catarina) (Monné, 2020b).

\section{Taxonomic Notes \\ Cerambycinae Latreille, 1802 \\ Cerambycini Latreille, 1802 \\ Sphallotrichina Martins \& Monné, 2002 \\ Metacriodion capixaba Fragoso, 1970}

(Figs. 20-21)

According to Fragoso (1970), Metacriodion capixaba differs from M. pictum (Waterhouse, 1880) by the elytra mostly orangish, by the sub-diamond inferior sutural macula on the elytra, and by the reddish tubercles on sides of mesocoxal cavities. All these features agree exactly with the specimen examined by us. However, the shape of the inferior sutural macula on the elytra is variable and may be sub-diamond in M. pictum too. Furthermore, the female of $M$. pictum examined by us has the same reddish tubercles on sides of mesocoxal cavities. However, the holotype of $M$. capixaba and the female examined by us do not have dense golden pubescence between the gibbosities of the pronotum, frons, vertex, and scutellum, while it is present on these areas of the holotype of M. pictum, and also in one female examined by us, and specimens examined through photographs (see Bezark, 2020).

Morvan \& Morati (2011) recorded M. pictum from French Guiana. However, the general color and absence of the golden pubescence suggest that the specimen examined by them is M. capixaba.

Material examined: BRAZIL, Espírito Santo: Linhares, 1 \%, 17.XI.2009, J.S. Santos col. (RNV).

\section{Hesperophanini Mulsant, 1839 \\ Hesperophanina Mulsant, 1839 \\ Potiaete maculata Martins \& Galileo, 1999}

(Figs. 23-29)

This species was described and remains known only from Brazil (Espírito Santo). The original description provided only a drawing of a male, probably the holotype. The female was never illustrated, and the only known specimen of this sex was destroyed during the fire in the MNRJ. Herein we illustrate both sexes of this species (including the male holotype).
Material examined: BRAZIL, Espírito Santo: Linhares, holotype male, 30.X.1992, J.S. Santos col. (MZSP); Linhares, $10^{\circ}, 1$ \%, 30.X.1992, J.S. Santos col. (RNV, female retained to MZSP); Aracruz, 1951'41"S, 40¹2'49"W, 1 \%, 17.XII.1997, J.A.C. Simões col. (SSA).

\section{Trachyderini Dupont, 1836 \\ Trachyderina Dupont, 1836 \\ Eriphus mexicanus Audinet-Serville, 1834}

(Fig. 22)

This species was described based on a single specimen from Mexico (no further details). Later, Buquet (1844) described Eriphus unipunctatus, but the type locality is unknown ("Hab. inconnue"). Chevrolat (1862) synonymized $E$. unipunctatus with E. mexicanus and indicated Mexico as the country where the species occurs. According to him (translated): "Collection of Mr. J. Thomson. The type of Serville no longer existed when I acquired almost all of the Cerambycidae from this author". Monné (1994a) indicated E. mexicanus as from Brazil (Espírito Santo and Rio de Janeiro), and Monné \& Fragoso (1996) confirmed this information. However, Monné \& Giesbert (1994) listed the species from Mexico and Panama. Usually, the inclusions of new records in this checklist were based on Giesbert's private collection, which is currently deposited at FSCA. It will be necessary to examine the specimens to confirm if they are E. mexicanus. If they are E. mexicanus, this indicate that $E$. mexicanus and $E$. unipunctatus are not the same species, due to the isolated geographical distribution.

The specimen examined by us agrees perfectly with the original descriptions and with the photograph of the holotype of $E$. unipunctatus, differing only by the absence of the black spot on base of the pronotum.

Material examined: BRASIL, Espírito Santo: Aracruz, 1 , 12.X.1986, J.B. Silva col. (MZSP, formerly SSA).

\section{Description of Unknown Female Lamiinae \\ Onciderini \\ Trestonia grisea Martins \& Galileo, 1990} (Figs. 30-34)

Trestonia grisea Martins \& Galileo, 1990: 87; Monné, 2020b: 864 (cat.)

Description: Coloration: Integument mostly dark brown; mouthparts dark reddish brown; anteclypeus reddish brown.

Head: About as wide as anterior area of prothorax. Frons subquadrate; abundantly micropunctate, with fine punctures interspersed; with yellowish-brown pubescence, somewhat abundant close to eyes, centrally, and close to clypeus, nearly absent on remaining surface. Area between antennal tubercles depressed centrally; abun- 



Figures 12-22. (12) Blabicentrus lineatus, female, dorsal habitus; (13) Pseudestola densepunctata, female, dorsal habitus; (14) Proceroblesthis prolata, male, dorsal habitus; (15) Butocrysa insignis, male, dorsal habitus; (16) Phoebella albomaculata, male, dorsal habitus; (17) Rhaphiptera affinis, male, dorsal habitus; (18) Desmiphora (Desmiphora) cirrosa, female, dorsal habitus; (19) Cipriscola fasciata, male, dorsal habitus. (20-21) Metacriodion capixaba, female: (20) dorsal view; (21) ventral view; (22) Eriphus mexicanus, female, dorsal view. 

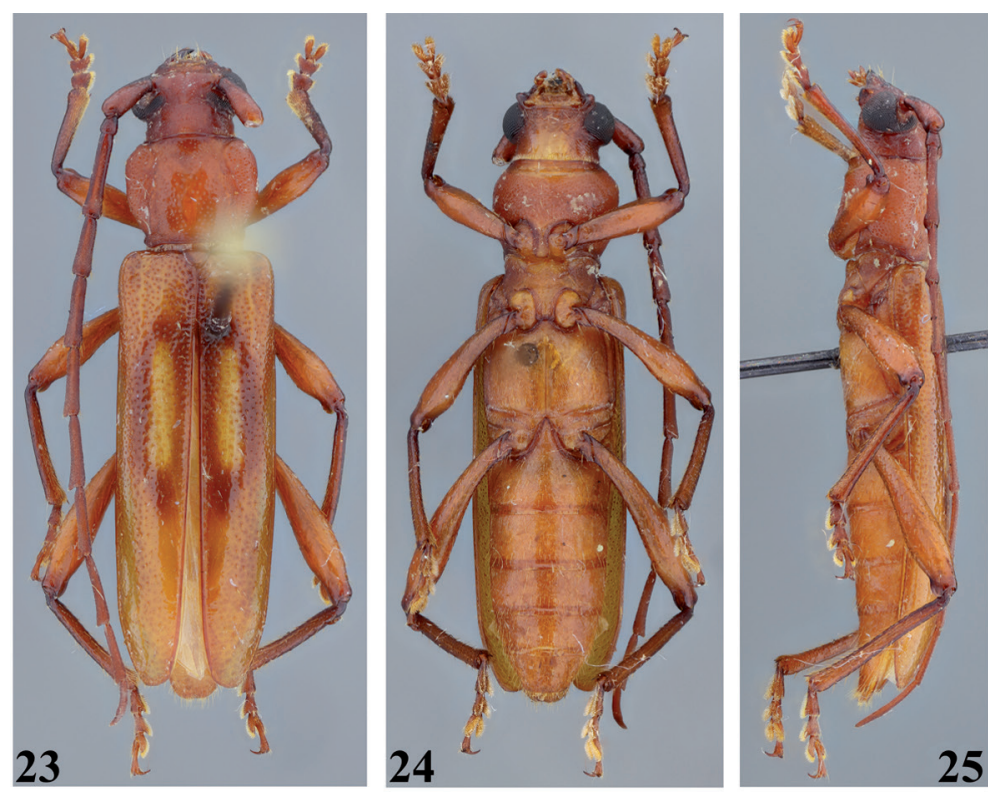

2526
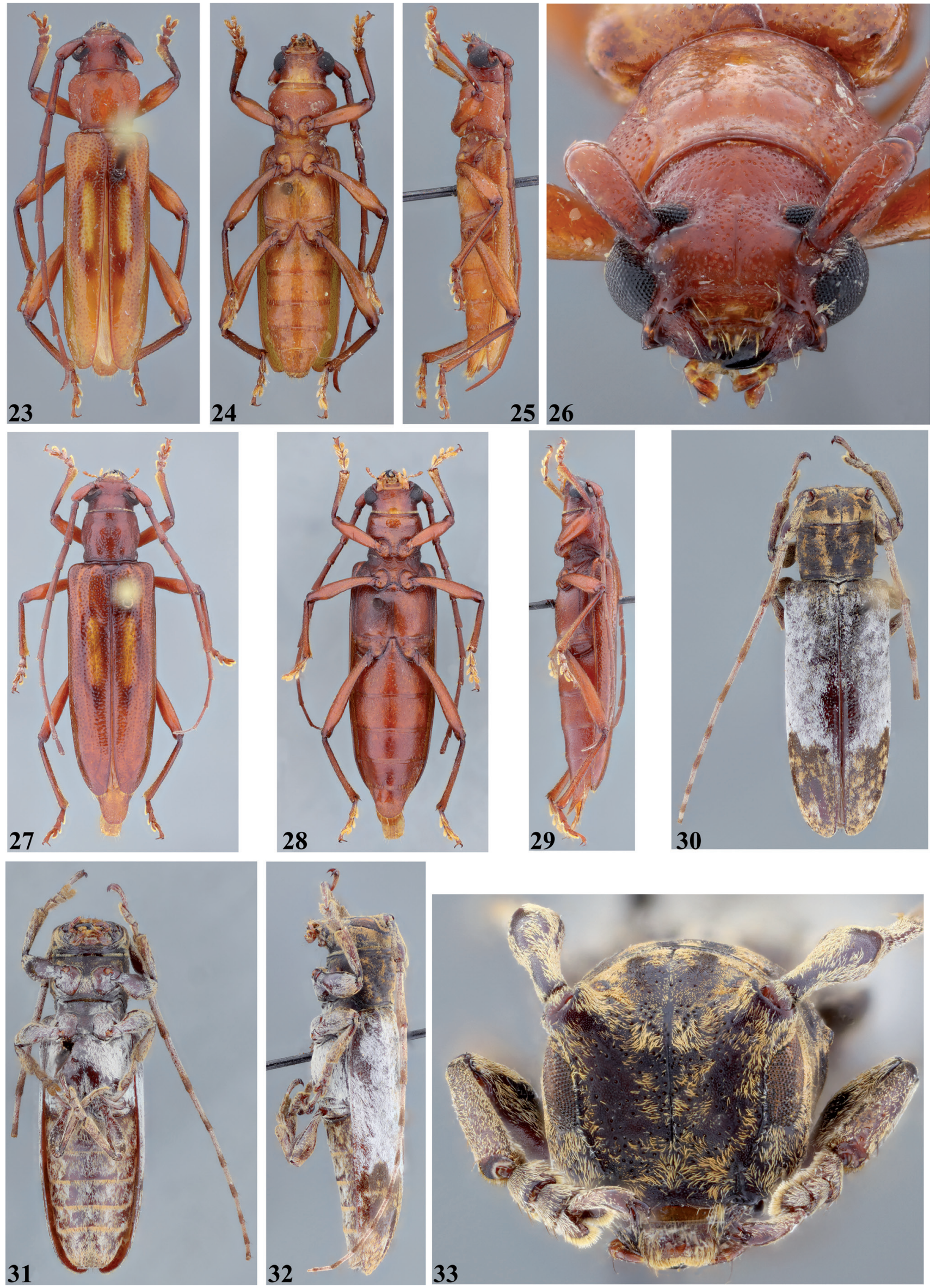

Figures 23-33. (23-26) Potiaete maculata, holotype male: (23) dorsal habitus; (24) ventral habitus; (25) lateral habitus; (26) head, frontal view. (27-29) Potiaete maculata, female: (27) dorsal habitus; (28) ventral habitus; (29) lateral habitus. (30-33) Trestonia grisea, female: (30) dorsal habitus; (31) ventral habitus; (32) lateral habitus; (33) head, frontal view. 
dantly punctate, with fine punctures interspersed; with abundant yellowish-brown pubescence partially obscuring integument anteriorly, shorter, sparser posteriorly. Remaining surface of vertex abundantly micropunctate (micropunctures finer and less distinct than on frons), with fine punctures interspersed (fine punctures distinctly sparser than on frons, especially toward prothorax); with almost M-shaped area with minute, nearly indistinct yellowish-brown pubescence centrally, from area between eyes, almost reaching prothoracic margin; remaining surface with dense yellowish-brown pubescence obscuring integument. Area behind eyes with dense yellowish-brown pubescence, somewhat sparser toward prothorax behind lower eye lobes. Genae finely, sparsely punctate (surface slightly rugose frontally), except for narrow smooth apex; with yellowish-brown pubescence not obscuring integument, except for glabrous smooth area. Antennal tubercles armed at apex with small rounded projection; sculpturing as on frons; with dense yellowish-brown pubescence, except for nearly glabrous center of frontal area; with a few short, erect dark setae close to lower eye lobe. Postclypeus very finely, abundantly punctate, with coarser punctures interspersed on wide central area, smooth laterally; wide central area with yellowish-brown pubescence, dense close to frons and laterally, nearly absent centrally toward anteclypeus; with tuft of long golden setae directed forward on each side close to anteclypeus; smooth lateral area glabrous. Labrum coplanar with anteclypeus at posterior $2 / 3$, oblique at anterior third; with sparse yellowish-brown pubescence on wide central area, with long, erect dark setae directed forward interspersed on coplanar area, glabrous on center of oblique area, with dense yellowish-brown pubescence on sides, and fringe of golden setae on anterior margin. Distance between upper eye lobes 0.76 times length of scape (0.48 times distance between outer margins of eyes); in frontal view, distance between lower eye lobes 1.12 times length of scape (0.71 times distance between outer margins of eyes). Antennae 1.5 times elytral length, reaching elytral apex at posterior third of antennomere IX. Scape with yellowish-brown pubescence partially obscuring integument. Pedicel with yellowish-brown pubescence partially obscuring integument, and a few short, erect brown setae interspersed ventrally. Antennomeres with dense grayish-white pubescence except for less dense, yellowish-brown pubescence on apex; antennomeres III-V with sparse, somewhat short, erect brown setae on inferior


Figures 34-37. (34) Trestonia grisea, holotype male, dorsal view. (35-37) Stenoeme annularis, female: (35) dorsal habitus; (36) ventral habitus; (37) metafemur. 
region of inner surface; antennomere III slightly sinuous. Antennal formula (ratio) based on length of antennomere III: scape $=0.87$; pedicel $=0.20 ; \mathrm{IV}=1.08 ; \mathrm{V}=0.80$; $\mathrm{VI}=0.72 ; \mathrm{VII}=0.66 ; \mathrm{VIII}=0.58 ; \mathrm{IX}=0.52 ; \mathrm{X}=0.46 ; \mathrm{XI}=0.42$.

Thorax: Prothorax wider than long, with short tubercle laterally placed about middle. Pronotum with anterior and posterior transverse sulci well marked; central area tumid, rugose, with irregular gibbosities; with one oblique yellowish-brown pubescent band on each side of central area, convergent from anterior to posterior margin; with longitudinal, irregular yellowish-brown pubescent band centrally, from anterior margin to near middle; with longitudinal yellowish-brown pubescent band on each side, nearly absent anteriorly, more distinct centrally and close to posterior margin; central area close to posterior margin with whitish pubescence; remaining surface with minute, slightly distinctly, sparse yellowish-brown pubescence. Sides of prothorax somewhat rugose centrally, coarsely, sparsely punctate posteriorly; with two irregular, fragmented, longitudinal yellowish-brown pubescent bands, on near pronotum, another near prosternum; remaining surface with minute, sparse, slightly distinct yellowish-brown pubescence. Prosternum nearly smooth; with dense yellowish-brown pubescence laterally, sparser close to procoxal cavities, glabrous or nearly so on remaining surface. Prosternal process glabrous anteriorly, with dense, slightly bristly yellowish-white pubescence on remaining surface, except for apex with shorter and sparser pubescence. Mesoventrite with minute yellowish-white pubescence not obscuring integument. Mesanepisternum with minute yellowish-white pubescence not obscuring integument, except for dense, long yellowish-white pubescence close to mesepimeron. Mesoventral process with minute yellowish-white pubescence except for denser, longer pubescence of same color on apex. Mesepimeron, metanepisternum, and most of metaventrite with dense grayish-white pubescence obscuring integument. Scutellum with dense white pubescence centrally, somewhat golden laterally. Elytra: Coarsely, abundantly punctate on basal half, punctures gradually finer, sparser toward apex on posterior half; apex individually rounded; base with yellowish-brown pubescence, and remaining anterior $2 / 3$ with dense white pubescence obscuring integument, with irregular, sparse yellowish-brown pubescence interspersed (posterior margin of this area oblique and irregular); posterior third with irregular, dense yellowish-brown pubescence, with areas with minute, slightly distinct yellowish-brown pubescence interspersed (also, with white pubescence interspersed on some areas). Legs: Femora with yellowish-brown pubescence dorsally, gradually whitish, with yellowish-brown pubescence interspersed toward ventral surface. Tibiae with dense yellowish-brown pubescence, nearly golden on apex, with irregular whitish pubescence interspersed.

Abdomen: Ventrites with white pubescence, with yellowish-brown pubescence interspersed, especially laterally (yellowish-brown pubescence more abundant on ventrite I), and also on central area of ventrite $\mathrm{V}$, and with glabrous, irregular areas interspersed; apex of ventrites I-IV with fringe of yellow pubescence; posterior area of ventrite $V$ with long, erect, sparse dark setae; central area of ventrite $\mathrm{V}$ triangularly depressed (depression gradually wider and deeper toward apex).

Dimensions in mm (1 \%): Total length, 13.90; prothoracic length, 2.20; anterior prothoracic width, 2.95; posterior prothoracic width, 2.80; maximum prothoracic width (between apices of lateral tubercles), 3.20; humeral width, 3.95; elytral length, 10.15 .

Material examined: BRAZIL, Espírito Santo (new state record): Aracruz, 1952'04"S, 40¹2'29"W, 1 \%, 29.01.1998, M.P. Santos col. (SSA). Santa Catarina: Hansa Humboldt (currently, Corupá), holotype male, XII.1929, A. Maller col. (MZSP).

Remarks: Female of T. grisea differs from male (Fig. 34) especially by the antennae much shorter, slightly surpassing elytral apex (longer than twice body length in male). Trestonia grisea, currently recorded for the Brazilian states of Bahia and Santa Catarina, and T. lateapicata Martins \& Galileo, 2010, currently recorded from Santa Cruz (Bolivia) and Goiás (Brazil) are very similar. Unfortunately, Martins \& Galileo (2010) did not compare them. Trestonia grisea differs from T. lateapicata by the absence of distinct arched band on posterior third of the elytra with inconspicuous pubescence (present in T. lateapicata; only males of this species are known). Additionally, the basal antennomeres are slender and sinuous in males of T. lateapicata, while they are stouter and not sinuous in T. grisea.

\section{Redescription \\ Oemini Lacordaire, 1868 \\ Oemina Lacordaire, 1868 \\ Stenoeme annularis Martins, 1980}

(Figs. 35-37)

Stenoeme annularis Martins, 1980: 224; Monné, 2020a: 610 (cat.).

Redescription: Female: Coloration: Head orangish, darker orange behind eyes; outer side of mandibles orangish on posterior $2 / 3$ except for black margins, black on posterior third; scape orangish with posterior quarter black; pedicel orangish; antennomeres III-X orangish with posterior area dark, dark brown on basal antennomeres, gradually brownish toward X; antennomere XI orangish. Pronotum and sides of prothorax brown; prosternum orangish with sides brownish. Ventral surface of meso- and metathorax dark brown except for orangish metaventral process. Scutellum brown. Elytra mostly orangish (more testaceous depending on light intensity), with basal area brownish. Femora dark reddish brown basally, gradually dark brown toward apex (extreme apex nearly black). Tibiae orangish on basal third, 
gradually darker toward dark brown apex. Tarsomeres I dark brown, remaining tarsomeres more reddish brown, especially on V. Ventrites most dark brown.

Head: Frons somewhat coarsely, densely, confluently punctate; with short, decumbent, very sparse yellowish setae. Vertex and area behind upper eye lobes with sculpturing as on frons, less so centrally close to pronotum; area between antennal tubercles and upper eye lobes slightly depressed (depression gradually acute toward posterior area); with sparse, decumbent yellowish setae. Area behind lower eye lobes striate-punctate; with sparse, decumbent yellowish setae, with long, erect, sparse setae of same color interspersed. Genae finely punctate close to eye, smooth on apex; with minute, sparse yellowish setae on punctate area, glabrous on smooth area. Postclypeus depressed, somewhat rugose-punctate on wide central area (less so centrally), smooth laterally; with short, decumbent, sparse yellowish setae on sides of wide central area (nearly absent centrally), glabrous laterally; with one long, erect brownish seta on each side of wide central area. Labrum concave; with long, erect yellowish-brown setae laterally, nearly glabrous on remaining surface except for short, sparse yellowish setae on anterior margin. Antennal tubercles moderately elevated, with blunt apex; basal area with sculpturing as on frons, apex smooth. Median groove distinct form clypeus to near prothoracic margin. Gulamentum nearly smooth, glabrous on posterocentral area; obliquely depressed toward anterior margin, opaque, finely rugose-punctate, with both, short and long, sparse yellowish setae between eyes. Eyes with a few minute yellowish setae interspersed among ommatidia. Distance between upper eye lobes 0.36 times length of scape $(0.23$ times distance between outer margins of eyes); in frontal view, distance between lower eye lobes 0.76 times length of scape ( 0.49 times distance between outer margins of eyes). Antennae 1.5 times elytral length, reaching elytral apex at apex of antennomere IX; scape cylindrical; with somewhat bristly, sparse yellowish setae; scape, pedicel and antennomeres with long, erect, sparse setae ventrally, yellowish on lighter area of basal antennomeres, brown on dark area, and more brownish from antennomere VI. Antennal formula (ratio) based on length of antennomere III: scape $=0.63$; pedicel $=0.09$; $\mathrm{IV}=1.02 ; \mathrm{V}=1.02 ; \mathrm{VI}=0.96 ; \mathrm{VII}=0.90 ; \mathrm{VIII}=0.79 ; \mathrm{IX}=0.69$; $\mathrm{X}=0.65 ; \mathrm{XI}=0.61$.

Thorax: Prothorax slightly longer than wide. Pronotum densely, finely punctate (punctures somewhat asperate on some areas), except for smooth elongate triangular area on center of posterior third; with yellowish pubescence not obscuring integument (more whitish depending on light intensity), slightly denser and longer laterally. Sides of prothorax finely, densely punctate close to pronotum, gradually finely, transversely striate toward prosternum; with yellowish pubescence not obscuring integument. Prosternum very finely, transversely striate, with fine punctures interspersed, except for smooth anterior area; with short, sparse yellowish pubescence, with long, moderately abundantly erect yellowish setae on sides of anterior third. Sides of meso- and metathorax with somewhat abundant yellowish pubescence laterally (more grayish-white depending on light intensity), nearly glabrous centrally, especially on metaventrite (pubescence sparse between sides and central area of metaventrite); mesoventrite opaque; central area of metaventrite shiny; sides of metaventrite with long, erect yellowish setae interspersed. Scutellum longitudinally sulcate centrally, glabrous. Elytra: Finely, densely punctate; with longitudinal carina from base to near apex on side of dorsal surface (another slightly distinct carina between the former and suture, absent toward apex); with short, yellowish-white pubescence distinctly not obscuring integument, longer, more abundant on epipleural margin and dorsal area close to apex. Legs: Femora with long, sparse yellowish setae, decumbent dorsally, erect ventrally; metafemora (Fig. 37) with long, erect differentiated setae dorsally just after middle (entirely dark brown or yellowish basally with apex dark brown). Protibiae with long, erect dark setae dorsally, shorter, denser, more yellowish ventrally. Meso- and metatibiae with somewhat long, erect, abundant setae, mostly yellowish on basal half, mostly dark on posterior half, setae denser on posterior third of dorsal surface (Fig. 37).

Abdomen: Ventrites with yellowish-white pubescence not obscuring integument, with long, erect setae of same color interspersed, except for glabrous apex of ventrites I-IV. Apex of ventrite V rounded.

Dimensions in mm (1 9 ): Total length, 16.75; prothoracic length centrally, 2.00; prothoracic width laterally, 2.15; anterior prothoracic width, 1.55; posterior prothoracic width, 1.70; maximum prothoracic width, 2.00; humeral width, 2.65; elytral length, 12.50 .

Material examined: BRAZIL, Bahia: Estrada Rio-Bahia, km 965, Motel da Divisa, 960 m, Encruzilhada, 1 paratype male, 1 paratype female, XI.1974, Seabra \& Roppa col. (MZSP). Espírito Santo (new state record): Aracruz, $19^{\circ} 48^{\prime} 45^{\prime \prime}$ S, 4008'49"W, 30.IX.1987, P.M. Vieira col. (MZSP, formerly SSA).

Remarks: Stenoeme annularis Martins, 1980 was described based on $3 \sigma^{\prime \prime}$ and 4 from Brazil (Bahia). The holotype male, and one male and $3 \%$ paratypes were deposited at MNRJ and were destroyed by fire. According to Martins (1980) (translated): "Near bellarmine, which I know only by the slide of the holotype, taken by J.S. Moure at the Paris museum. The antennae of the holotype [S. bellarmini] are entirely dark, and the metafemora do not have long, erect black setae, present and very characteristic in both sexes of S. annularis, which, furthermore, have antennomeres reddish with black apex". As the female was briefly described in the original description and redescription, we take the opportunity to redescribe it.

Currently, it is known from Brazil (Bahia, Minas Gerais) (Monné, 2020a). 


\section{Key to species of Stenoeme (adapted from Martins, 1997b)}

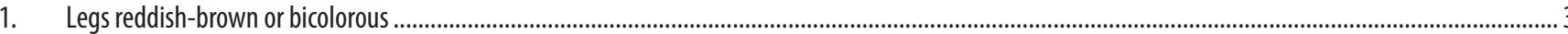

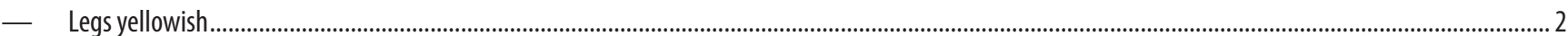

2(1). Sides of elytra brownish; antennae dark brown; prothorax in male slightly longer than wide, with strongly basal constriction. Brazil (Espírito Santo) .............

S. kempfi Martins, 1980

- Sides of elytra not brownish; antennae reddish-brown basally, gradually yellowish-brown toward apex; prothorax in male distinctly longer than wide, without strong basal constriction. Brazil (Bahia).............................................................................................................. furca Nascimento \& Bravo, 2018

3(1). Elytra with long and dark setae interspersed between short yellowish setae; prothorax in male without distinct basal constriction. Brazil (Goiás, Pernambuco) S. iheringi Gounelle, 1909

- Elytral setae yellowish, short, without long and erect setae interspersed; prothorax in male with distinct basal constriction......

4(3). Antennomeres bicolorous. Brazil (Bahia, Minas Gerais, Espírito Santo). S. annularis Martins, 1980

- Antennomeres unicolorous

5(4). Scape not strongly enlarged at apex, basal width about half of maximum width. Brazil (Bahia, Piauí) ..................................

- Scape distinctly enlarged at apex, basal width of the scape about 1.5 times of maximum width. Paraguay......

S. bellarmini Gounelle, 1909 S. aguilari Galileo \& Martins, 2010

Note: Galileo \& Martins (2010) separated S. bellarmini and S. aguilari as follows (translated): "It differs from S. bellarmini by the general color black and dark brown, with the apex of the elytra with same color (in S. bellarmini the general color is brownish ocher and the elytra are darkened on apex)". We believe that these differences do not allow separating them. This because the overall color is often somewhat variable in species of Stenoeme, and we did not find other morphological differences. Unfortunately, we do not have specimens of S. bellarmini to further comparison.

\section{New Species \\ Cerambycinae \\ Neoibidionini Monné, 2012 \\ Compsina Martins \& Galileo, 2007 \\ Microibidion fiuzai sp. nov. (Figs. 38-46)}

\begin{abstract}
Description: Holotype female (Figs. 38-42): Coloration: Integument mostly reddish brown, darker on prothorax (some areas more brown); palpi yellowish-brown; antennomeres III-XI orangish brown. Elytra with large subelliptical pale yellow macula on basal half, and nearly entirely light reddish brown on posterior quarter. Femora orangish-brown on peduncle, black on club; tibiae and tarsi orangish brown.
\end{abstract}

Head: Frons abundantly micropunctate close to postclypeus, coarsely, confluently punctate on remaining surface; glabrous. Vertex glabrous; area between antennal tubercles with sculpturing as on posterior area of frons; area between upper eye lobes somewhat coarsely, shallowly, sparsely punctate; remaining surface minutely, densely striate. Area behind upper eye lobes densely micropunctate; glabrous, with a few long, erect brownish setae close to eye; area behind lower eye lobes tumid, smooth close to eye, densely micropunctate on remaining surface; glabrous. Genae very finely, abundantly punctate, except for smooth apex; glabrous. Antennal tubercles finely, sparsely punctate (punctures denser frontally). Postclypeus with one long, erect brownish seta on each side. Labrum with somewhat long, erect brownish setae. Gulamentum smooth, glabrous posteriorly, striate, with long, sparse, erect brownish setae anteriorly. Distance between upper eye lobes 0.68 times length of scape ( 0.42 times distance between outer margins of eyes); in frontal view, distance between lower eye lobes 0.68 times length of scape ( 0.42 times distance be- tween outer margins of eyes). Antennae 1.8 times elytral length, reaching elytral apex at posterior sixth of antennomere IX. Scape with decumbent, short and sparse yellowish setae; pedicel with decumbent, short and sparse yellowish pubescence, with long, erect yellowish-brown setae ventrally; antennomeres with yellowish pubescence not obscuring integument, denser toward $\mathrm{Xl}$; antennomeres III-VI with long, erect yellowish-brown setae ventrally. Antennal formula (ratio) based on length of antennomere III: scape $=0.68$; pedicel $=0.18$; IV $=0.68$; $\mathrm{V}=0.68 ; \mathrm{VI}=0.68 ; \mathrm{VII}=0.67 ; \mathrm{VIII}=0.65 ; \mathrm{IX}=0.63 ; \mathrm{X}=0.56$; $\mathrm{XI}=0.77$.

Thorax: Prothorax distinctly longer than wide; sides sinuous (anterior and posterior constrictions well marked). Pronotum finely, sparsely punctate; posterior area somewhat shagreened; with longitudinal, slightly conspicuous yellowish-white pubescent band centrally, from base to apex. Sides of prothorax nearly glabrous; finely sparsely punctate; posterior region somewhat shagreened. Prosternum finely, sparsely punctate on sides of posterior $2 / 3$, very finely transversely striate centrally, somewhat shagreened laterally close to procoxal cavities; glabrous. Central area of prosternal process notably narrow. Ventral surface of mesothorax mostly somewhat shagreened; mesanepisternum and mesepimeron with yellowish-white pubescence not obscuring integument. Apex of mesoventral process widened posteriorly (flap-shaped), with distal margin distinctly concave. Metanepisternum nearly glabrous anteriorly, with dense yellowish-white pubescence posteriorly. Metaventrite with very short and sparse yellowish setae. Scutellum with abundant yellowish-white pubescence not obscuring integument. Elytra: Coarsely, somewhat abundantly punctate on basal half, punctures gradually finer, sparser toward apex; apex bispinose (outer spine longer); with long, erect, sparse yellowish setae. Legs: 



Figures 38-46. Microibidion fiuzai sp. nov. (38-42) Holotype female: (38) dorsal habitus; (39) ventral habitus; (40) prosternal process and mesoventral process; (41) head, frontal view; (42) lateral view. (43-46) Paratype female: (43) dorsal habitus; (44) head, frontal view; (45) lateral view; (46) ventral habitus. 
Femoral club somewhat shagreened; profemora nearly glabrous; meso- and metafemora with short, sparse, decumbent yellowish setae, with long, erect, sparse yellowish setae interspersed. Tibiae with sparse, short, nearly decumbent yellowish setae dorsally and laterally, with long, erect setae of same color near apex, and distinctly denser pubescence ventrally on protibiae, bristly, longer ventrally on posterior third of meso- and metatibiae.

Abdomen: Ventrites with short, very sparse yellowish setae. Apex of ventrite $V$ rounded.

\section{Dimensions in $\mathbf{~ m m ~ ( f e m a l e s , ~ h o l o t y p e - p a r a t y p e ) : ~}$} Total length, 5.95-5.30; prothoracic length, 1.30-1.10; anterior prothoracic width, $0.90-0.75$; posterior prothoracic width, 0.80-0.70; humeral width, 1.20-1.05; elytral length, 3.90-3.45.

Type material: Holotype female from BRAZIL, Espírito Santo: Sooretama, Fazenda Cupido e Refúgio, 1903'44"S, $39^{\circ} 58^{\prime} 36^{\prime \prime} \mathrm{W}, 1$ o' $^{\prime \prime}$ 16.XI.2015, M.T. Tavares \& S. Freitas col. (MZSP, formerly UFES). Paratype female, same data as holotype except UFES \# 159511 (UFES).

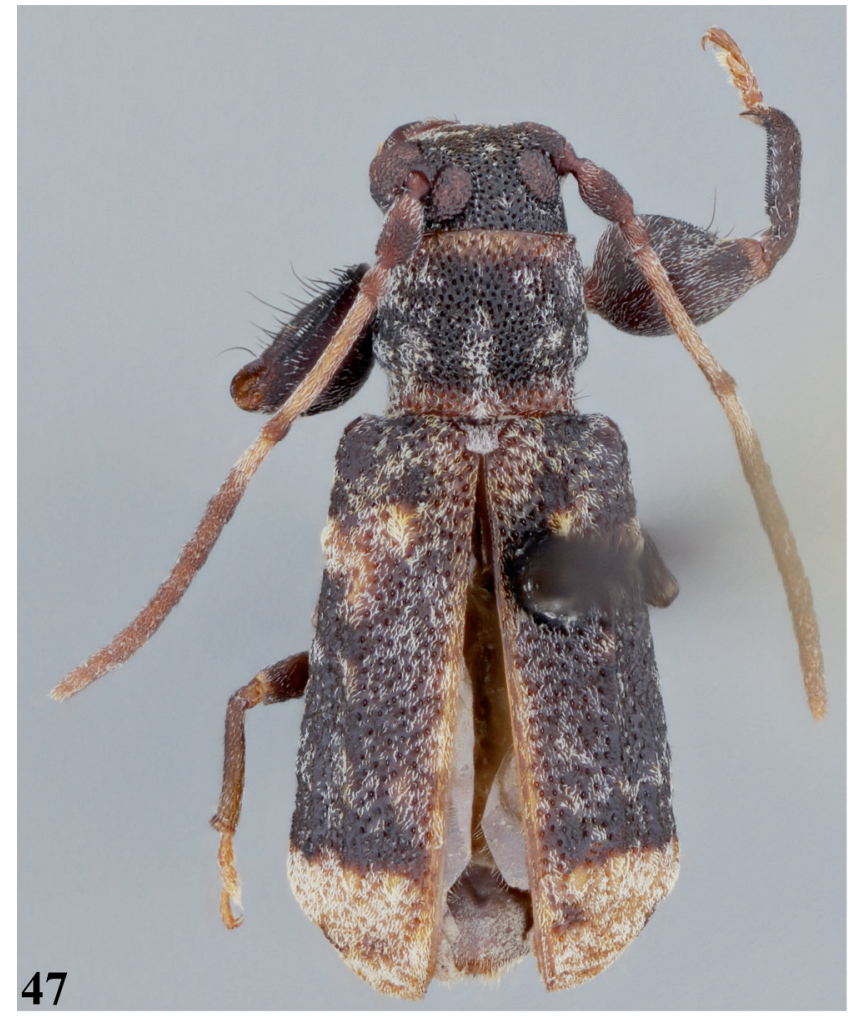

Etymology: The new species is dedicated to Paulo Sérgio Fiuza Ferreira, former Professor at the Universidade Federal de Viçosa (Minas Gerais, Brazil), expert on taxonomy of Heteroptera, especially Miridae, who introduced the fourth author to the study of insects.

Remarks: Microibidion fiuzai sp. nov. is similar to M. exiguum Martins, 1962 (see photograph of the holotype at Bezark, 2020), but differs by the upper eye lobes with three rows of ommatidia (two in M. exiguum), setae on ventral surface of the antennomeres distinctly short (longer in M. exiguum), pronotum without long and erect setae (present in $M$. exiguum), elytral apex bispinose (with spine only at outer angle in M. exiguum).

\section{Lamiinae \\ Eupromerini Galileo \& Martins, 1995 Iquiracetima venturai sp. nov.}

(Figs. 47-50)

Description: Holotype female: Coloration: Integument mostly dark brown; mouthparts, and posterocentral area
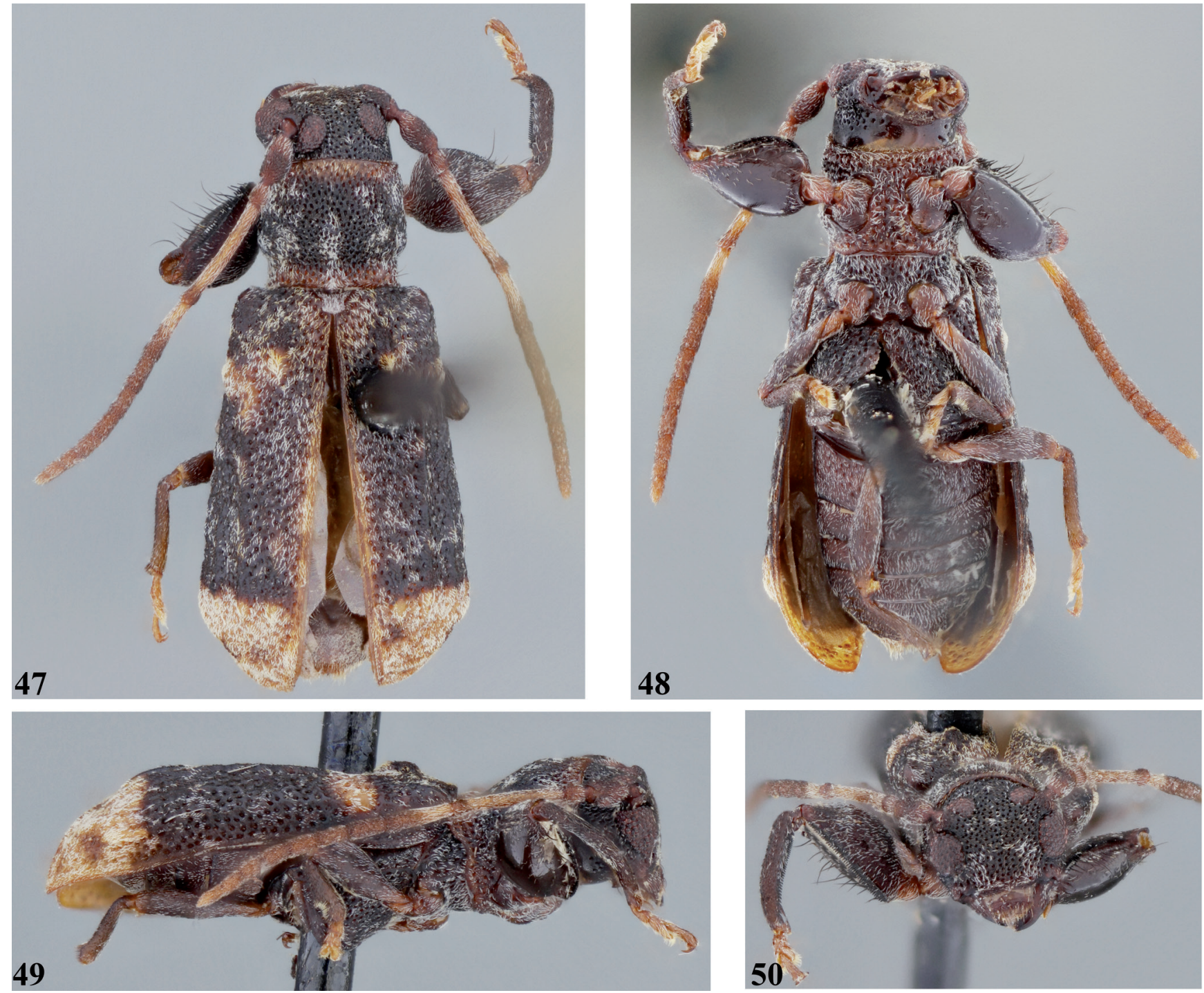

Figures 47-50. Iquiracetima venturai sp. nov., holotype female: (47) dorsal habitus; (48) ventral habitus; (49) lateral habitus; (50) head, frontal view. 
of gulamentum reddish brown; scape brown; pedicel, anterior $4 / 5$ of antennomere III, and basal half of antennomere IV yellowish brown; posterior fifth of antennomere III, posterior half of antennomere IV, and antennomeres V-XI brown. Anterior and posterior areas of prothorax reddish brown (including apex of prosternal process). Elytra with irregular orangish macula on each side of anterior quarter, nearly entirely orangish along suture, and nearly entirely orangish on posterior fifth. Coxae, trochanters, and base of meso- and metafemora reddish-brown; remaining surface of meso-and metafemora, and mesoand metatibiae brown (somewhat dark reddish brown depending on light intensity); tarsi reddish brown.

Head: Frons, vertex, and area behind eyes somewhat coarsely, abundantly punctate; with sparse yellowish-white pubescence on sides of frons and close to upper eye lobes. Genae finely, transversely striate, with sparse punctures interspersed, glabrous. Antennal tubercles somewhat finely, densely punctate, glabrous. Postclypeus with sculpturing as on frons. Labrum with a few long, erect dark setae posteriorly; with dense yellowish setae anteriorly. Gulamentum mostly smooth, glabrous, except for narrow anterior area slightly depressed, micropunctate, and with sparse yellowish-white pubescence. Distance between upper eye lobes 0.62 times length of scape $(0.23$ times distance between outer margins of eyes); in frontal view, distance between lower eye lobes 1.37 times length of scape $(0.50$ times distance between outer margins of eyes). Antennae 1.10 times elytral length, reaching posterior fifth of elytra; with yellowish-white pubescence not obscuring integument. Antennomere III slightly sinuous. Antennal formula (ratio) based on length of antennomere III: scape $=0.43$; pedicel $=0.21 ; \mathrm{IV}=0.57 ; \mathrm{V}=0.32$; $\mathrm{VI}=0.27 ; \mathrm{VII}=0.24 ; \mathrm{VIII}=0.21 ; \mathrm{IX}=0.21 ; \mathrm{X}=0.16 ; \mathrm{XI}=0.21$.

Thorax: Prothorax slightly wider than long, with distinct constriction posteriorly. Pronotum strongly convex at anterior $4 / 5$, flat at posterior fifth; slightly, widely longitudinally sulcate on each side of central are in convex area; coarsely, densely punctate; with yellowish-white pubescence close to anterior margin, on flat area (denser and more distinct than on anterior area), and three longitudinal pubescent bands of same color on posterior half, one centrally, another on each side; anterior area with short; remaining surface nearly glabrous. Sides of prothorax with sculpturing as on pronotum; with yellowish-white pubescence not obscuring integument (whiter depending on light intensity). Prosternum and prosternal process coarsely, confluently punctate; with yellowish pubescence not obscuring integument (whiter depending on light intensity). Ventral surface of meso- and metathorax coarsely, abundantly punctate (punctures sparser on center of mesoventrite); with grayish-white pubescence not obscuring integument. Scutellum with dense grayish-white pubescence. Elytra: Coarsely, densely punctate (punctures confluent on some areas); with five elevated longitudinal carinae, first on center of anterior quarter of dorsal surface, one near suture on posterior quarter, only reaching base of orangish posterior area, one dorsally, slightly oblique, from anterior fifth to base of orangish posterior area, one close to lateral curvature, placed on posterior quarter, slightly longer than posterior innermost carina, and another on inclined area, small, distinct only on beginning of orangish area; posterior tubercles slightly elevated; with yellowish pubescence not obscuring integument, denser on orangish areas. Legs: Profemora with yellowish-white pubescence dorsally, not obscuring integument, nearly glabrous ventrally except for apex with sparse yellowish-white pubescence; with long, erect, somewhat sparse dark setae on frontal depressed area. Meso- and metafemora and tibiae with yellowish-white pubescence not obscuring integument.

Abdomen: Ventrites with grayish-white pubescence not obscuring integument.

Dimensions in $\mathrm{mm}$ : Total length, 4.30; prothoracic length, 0.90; anterior prothoracic width, 0.95; posterior prothoracic width, 0.90; maximum prothoracic width, 1.05; humeral width, 1.30; elytral length, 2.90.

Type material: Holotype female from BRAZIL, Espírito Santo: Aracruz, $19^{\circ} 49^{\prime} 35^{\prime \prime} \mathrm{S}, 40^{\circ} 10^{\prime} 88^{\prime \prime} \mathrm{W}, 02 . I I I .1988$, P.M. Vieira col. (MZSP, formerly SSA).

Etymology: The new species is dedicated to José Aires Ventura (Instituto Capixaba de Pesquisa, Assistência Técnica e Extensão Rural (Incaper, Espírito Santo, Brazil). After coming from Angola at the beginning of his career, dedicated to various works in the Brazilian state of Espírito Santo, especially in the area of phytopathology.

Remarks: Iquiracetima venturai sp. nov. is similar to l. egeri Wappes et al., 2017 (see photograph of the holotype at Bezark, 2020), but differs as follows: frons and vertex with slightly conspicuous pubescence (distinct in I. egeri); elytra with irregular orangish macula on anterior region (absent in I. egeri); posterior tubercles of the elytra slightly elevated (strongly elevated in I. egeri); elytral punctures coarser and denser (finer and slightly sparser in I. egeri); anterodorsal innermost carina slightly elevated, not triangular-shaped (triangular shaped in I. egeri). It differs from I. ceruri Galileo \& Martins, 2008 (see photograph of the holotype at Bezark, 2020), by the antennomeres V-XI brown (orangish in I. ceruri), and elytra without several irregular orangish areas throughout (present in I. ceruri).

\section{Hemilophini \\ Adesmus culiki sp. nov. (Figs. 51-54)}

Description: Holotype female: Coloration: Head mostly black; mouthparts reddish brown except for pale yellow palpomeres (apex of last palpomeres brownish); anteclypeus orangish brown on wide central area, black close to margins; antennae and mandibles black. Prothorax and ventral surface of meso- and metathorax black. Basal half of elytra reddish brown except for two large, subcir- 
cular black maculae on center of dorsal surface, somewhat small, elongated black macula close to suture near posterior half, and elongated black macula on center of sides; posterior half black; limit between reddish-brown and black areas irregular. Legs orangish brown, except for dark brown tarsal claws. Ventrites black.

Head: Proportionally large, slightly wider than prothorax. Frons finely, somewhat sparsely punctate (punctures sparser centrally close to clypeus); with minute, nearly indistinct yellowish-brown pubescence, with a few long, erect setae of same color close to eyes. Vertex and area behind upper eye lobes finely rugose-punctate (less so centrally on vertex close to prothorax); with yellowish-brown pubescence not obscuring integument (nearly indistinct depending on angle of view; brownish depending on light intensity); with a few long, erect brownish setae close to eyes. Area behind lower eye lobes distinctly tumid close to eye; finely punctate (punctures coarser than on vertex); with dense silvery pubescence on tumid area (more golden depending on light angle and intensity). Genae slightly shorter than lower eye lobe; finely punctate close to eye, micropunctate on remaining surface, except for smooth apex; with yellowish-brown pubescence not obscuring integument, except for glabrous smooth area; with a few short, erect brownish setae interspersed toward posterior area. Antennal tubercles moderately elevated; densely micropunctate, with fine sparse punctures interspersed; pubescence as on frons, with a few long, erect brown setae interspersed on frontal base. Postclypeus finely, sparsely punctate on wide central area, smooth laterally; punctate area with pubescence as on frons, and smooth areas glabrous; with one long, erect brown seta on each side of wide central area. Labrum coplanar with anteclypeus at posterior $2 / 3$, oblique at anterior third; smooth close to anteclypeus and on anterior third, somewhat coarsely punctate between these two areas; with long, sparse, erect brownish setae on punc-
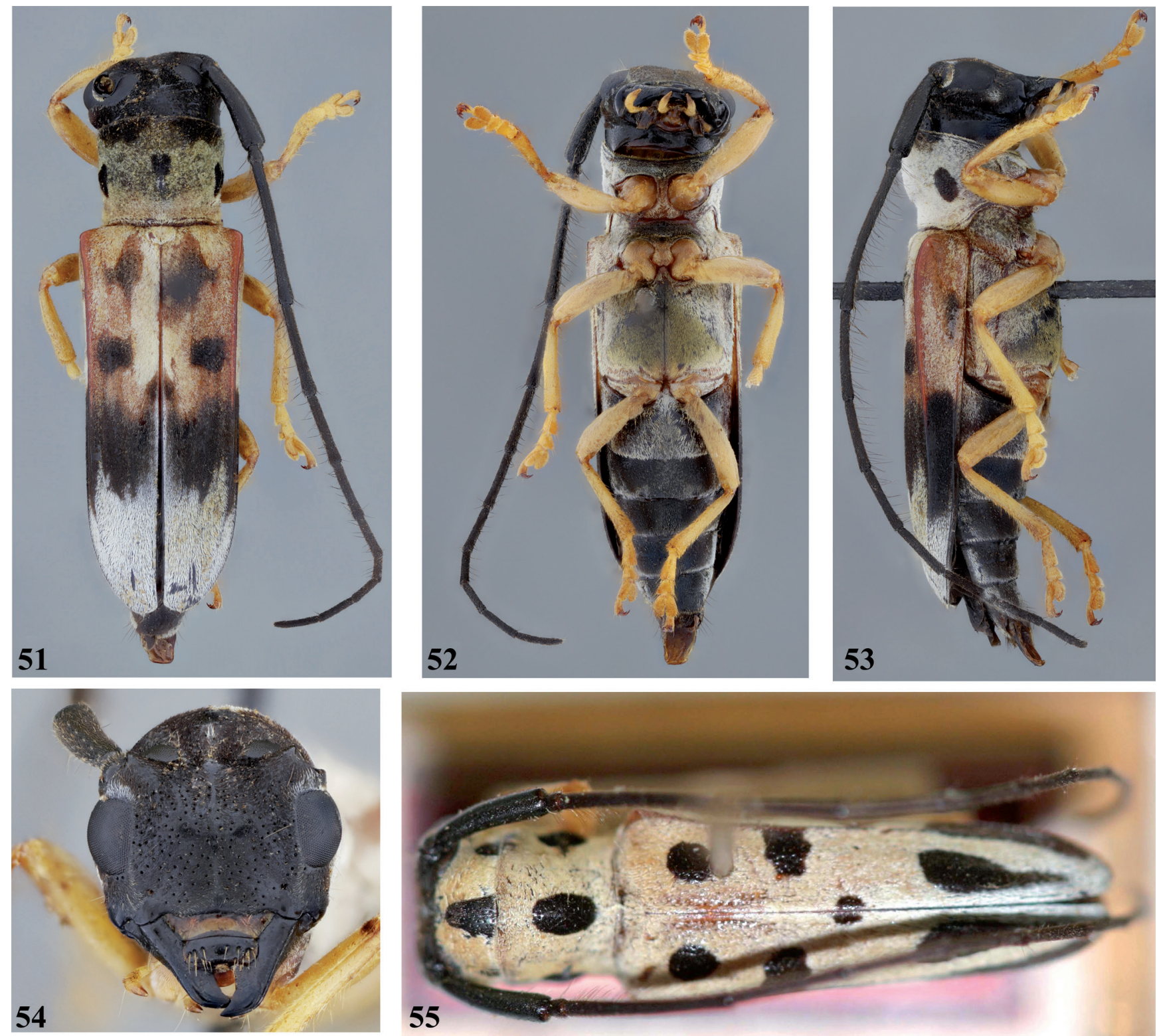

Figures 51-55. (51-54) Adesmus culiki sp. nov., holotype female: (51) dorsal habitus; (52) ventral habitus; (53) lateral habitus; (54) head, frontal view. (55) Adesmus seabrai, holotype male, dorsal habitus (by Steven W. Lingafelter). 
tate area. Distance between upper eye lobes 0.41 times length of scape ( 0.28 times distance between outer margins of eyes); in frontal view, distance between lower eye lobes 0.94 times length of scape ( 0.63 times distance between outer margins of eyes). Antennae 2.0 times elytral length, reaching elytral apex at posterior fifth of antennomere VII. Scape, pedicel and antennomeres with yellowish-white pubescence not obscuring integument, slightly yellowish toward distal segments; scape, pedicel and antennomeres III-VIII with long, erect brownish setae ventrally (gradually shorter and sparser toward VIII, sparser on scape and pedicel); dorsal apex of antennomeres III-X with a few somewhat short, erect brownish setae. Antennal formula (ratio) based on length of antennomere III: scape $=0.65$; pedicel $=0.09 ; \mathrm{IV}=0.62 ; \mathrm{V}=0.50$; $\mathrm{VI}=0.47 ; \mathrm{VII}=0.41 ; \mathrm{VIII}=0.38 ; \mathrm{IX}=0.35 ; \mathrm{X}=0.32 ; \mathrm{XI}=0.31$.

Thorax: Prothorax slightly wider than long; sides sinuous, with rounded gibbosity about middle. Pronotum oblique from anterior margin to posterior quarter, then somewhat abruptly sloped and becoming flat toward posterior margin; carina-shaped centrally from anterior margin to posterior quarter (slightly more distinctly centrally); with dense silvery pubescence obscuring integument (more yellowish depending on light intensity and angle source), except for brownish pubescence not obscuring integument on each side of anterior quarter, slightly more yellowish on central area of anterior quarter (especially depending on angle of view), dark pubescence not obscuring integument centrally, and subelliptical area with brownish pubescence not obscuring integument on each side of central area (extended to sides of prothorax). Sides of prothorax with dense silvery pubescence, gradually more yellowish brown toward ventral surface; with a few long, erect brownish setae interspersed. Prosternum coarsely, sparsely punctate; with abundant grayish-white pubescence, but not obscuring integument; prosternal process with yellowish pubescence. Mesoventrite coarsely punctate; nearly glabrous centrally, with yellowish pubescence laterally. Mesanepisternum with dense grayish-white pubescence; mesepimeron with dense yellowish-brown pubescence, longer than on mesanepisternum. Mesoventral process with yellowish pubescence not obscuring integument; sides flap-shaped near apex. Metanepisternum with dense grayish-white pubescence, yellower basally and close to superior margin. Metaventrite with dense grayish-white pubescence laterally, and dense golden pubescence on triangular central area. Scutellum with dense yellowish pubescence. Elytra: Somewhat coarsely, abundantly punctate on basal half, nearly smooth on posterior half; apex obliquely truncate (almost uniformly rounded); reddish-brown basal half of elytra with silvery pubescence, distinctly denser on wide band along suture, appearing to be yellower due to the integument color, especially depending on angle of view, dorsally interspersed with irregular areas with short golden pubescence, laterally with distinct, oblique golden pubescent band starting on humerus and involving de black macula; black maculae on basal half with yellowish-white pubescence not obscuring integument, appearing to be darker due to the integument color, denser on anterior macula; lateral black macula with golden pubescence not obscuring integument; anterior region of posterior half with minute yellowish-white pubescence distinctly exposing integument; posterior third with dense white pubescence. Legs: Femora with short yellowish pubescence not obscuring integument. Tibiae with yellowish pubescence, sparser on protibiae, with long, erect yellowish setae interspersed.

Abdomen: Ventrite I with dense grayish-white pubescence obscuring integument; ventrites II-V with minute grayish-white pubescence, abundant but not obscuring integument (slightly distinct depending on angle of view), denser and longer laterally, especially on IV and V. Posterior area o ventrite V with long, erect, somewhat sparse dark setae; posterior margin concave.

Dimensions in mm: Total length, 17.20; prothoracic length, 3.00; anterior prothoracic width, 3.60; posterior prothoracic width, 3.45; humeral width, 4.75; elytral length, 11.20.

Type material: Holotype female from BRAZIL, Espírito Santo: Aracruz, 1949'02"S, 40¹0'00"W, 08.XII.1995, J.A.C. Simões col. (MZSP, formerly SSA).

Etymology: The new species is dedicated to Mark Paul Culik, an American entomologist who has been working for 20 years on a voluntary basis at Instituto Capixaba de Pesquisa Assistência Técnica e Extensão Rural (Incaper, Expírito Santo, Brazil).

Remarks: Adesmus culiki is similar to A. seabrai Lane, 1959 (Fig. 55), also known only from the Brazilian state of Espírito Santo, by the black macula on pronotum and basal half of the elytra, and color of the legs, but differs: head lacking dense white pubescence (present in males and females of $A$. seabrai); posterior third of the elytra entirely with white pubescence (with on large area without dense white pubescence dorsally and laterally on posterior half, sometimes fused apically, in A. seabrai); area of elytra after middle with wide region with slightly conspicuous pubescence (absent in A. seabrai). Chromatic gender dimorphism was already reported in Hemilophini: Phoebe ornator (Tippmann, 1960) (Perger et al., 2017). However, even in large series of $P$. ornator the pubescence on dorsal surface of the elytra is nearly identical in males and females. Furthermore, the holotype of $A$. seabrai is a female and does not show chromatic differences with males of the species, as well as the 27 specimens (males and females) examined.

\section{Xenofreini Aurivillius, 1923 Xenofrea simplicioi sp. nov. (Figs. 56-59)}

Description: Holotype male. Integument mostly dark brown; frons somewhat dark reddish brown; anteclypeus and labrum orangish brown. 
Head: Frons abundantly micropunctate; with minute light yellowish-brown pubescence not obscuring integument. Vertex with sculpturing as on frons; with minute yellowish-brown pubescence, more conspicuous between upper eye lobes, nearly absent centrally toward prothoracic margin. Area behind upper eye lobes, very finely, densely, confluently punctate; with yellowish-brown pubescence, moderately dense and longer close to eye, shorter slightly, sparser, slightly distinct on remaining surface. Area behind lower eye lobes with dense yellowish-brown pubescence close to eye, gradually widened from area between lobes to middle of lobe, then gradually narrowed toward inferior margin of lobe, remaining surface with minute, nearly inconspicuous pubescence of same color. Genae micropunctate, nearly glabrous, except for short, sparse yellowish-brown pubescence close to eye; with on long, erect dark seta close near eye. Postclypeus nearly smooth and glabrous, with a few long, erect dark setae. Labrum with short, decumbent, sparse yellowish setae, especially on transverse central area. Distance between upper eye lobes 0.27 times length of scape $(0.18$ times distance between outer margins of eyes); in frontal view, distance between lower eye lobes 0.67 times length of scape ( 0.46 times distance between outer margins of eyes). Antennae 1.8 times elytral length, reaching elytral apex at posterior fifth of antennomere VIII; with yellowish pubescence not obscuring integument, slightly denser toward distal antennomeres. Antennal formula (ratio) based on length of antennomere III: scape $=0.73$; pedicel $=0.19$; IV $=0.97$; $\mathrm{V}=0.65 ; \mathrm{VI}=0.61 ; \mathrm{VII}=0.56 ; \mathrm{VIII}=0.54 ; \mathrm{IX}=0.51 ; \mathrm{X}=0.49$; $\mathrm{XI}=0.51$.


Figures 56-59. Xenofrea simplicioi sp. nov., holotype female: (56) dorsal habitus; (57) lateral habitus; (58) ventral habitus; (59) head, frontal view. 
Thorax: Prothorax wider than long; sides with large, rounded protuberance centrally. Pronotum with anterolateral angles slightly projected; somewhat finely, abundantly punctate (punctures confluent in some areas); with dense yellowish-brown pubescence except for almost $X$-shaped area with pubescence distinctly sparser, from anterior margin to just after middle (anterior arms of " $\mathrm{X}$ " shorter than posterior ones). Sides of prothorax with dense yellowish-brown pubescence close to pronotum, slightly less dense toward ventral surface. Prosternum with yellowish-brown pubescence not obscuring integument (lighter than on pronotum). Narrowest area of prosternal process about 0.25 times width of procoxal cavity; with yellowish-brown pubescence not obscuring integument, denser than on central area of prosternum. Ventral surface of mesoand metathorax with dense yellowish-brown pubescence laterally, sparser more yellowish-white centrally. Mesoventral process distinctly narrower than mesocoxal cavity. Scutellum with yellowish-brown pubescence partially obscuring integument. Elytra: Coarsely, abundantly punctate on anterior $3 / 4$, punctures finer, sparser on posterior quarter; nearly parallel-sided in anterior $3 / 4$, strongly narrowed toward sutural angle in posterior quarter (together, posterior quarter triangularly-shaped); with wide, slightly oblique carina dorsally, from about anterior quarter to posterior quarter; outer side of dorsal carina depressed from middle to posterior quarter; in side view, posterior fifth distinctly oblique, with its anterior area gibbose, especially laterally; anterior third with dense yellowish-brown pubescence, except for areas with minute, slightly conspicuous brownish pubescence, one wide, oblique band from middle of dorsal surface to near suture, one irregular macula on basal area (as a fragmented continuation of the anterior band), another wide, slightly oblique, from sides of dorsal surface to epipleural margin; area close to apex of anterior third with rectangular region dorsally (near suture) with minute, slightly conspicuous brownish pubescence (this area surrounded by yellowish-brown pubescence); central third with dense yellowish-white pubescence centrally and on entire area close to anterior third, with yellowish-brown pubescence on remaining surface, with large irregular areas with minute, slightly conspicuous brownish pubescence interspersed; posterior third with large yellowish-brown pubescent band close to central third, from suture to epipleural margin, oblique dorsally, transverse laterally; posterior quarter with large, irregular area with minute, slightly conspicuous brownish pubescence, except for area close to apex with yellowish-brown pubescence. Legs: Femora with yellowish-brown pubescence dorsally and laterally, more yellowish-white ventrally. Pro- and mesotibiae mostly with yellowish-white pubescence except for apex of protibiae with pubescence less conspicuous and darker, and apex of dorsal surface of mesotibiae with dark pubescence; metatibiae mostly with yellowish pubescence, lighter on some areas, except for apex with pubescence shorter and less conspicuous (appearing to be dark due to the integument color).
Abdomen: Ventrites with yellowish-brown pubescence laterally, yellowish-white, sparser centrally, except for apex of I-IV with fringe of yellowish-brown pubescence. Posterior area of ventrite $\mathrm{V}$ slightly depressed centrally, with posterior margin truncate.

Dimensions in $\mathrm{mm}$ : Total length, 4.85; prothoracic length, 1.00; anterior prothoracic width, 1.20; posterior prothoracic width, 1.25; maximum prothoracic width, 1.40; humeral width, 1.85; elytral length, 3.55.

Type material: Holotype female from BRAZIL, Espírito Santo: Aracruz, 1951'29"S, 40¹2'00"W, 22.V.1995, J.A.C. Simões col. (MZSP, formerly SSA).

Etymology: The new species is dedicated to José Simplício dos Santos, a retired employee of the RNV. He was responsible for insect collection, assembly and conservation of the entomological collection of the RNV, serving in a very dedicated way as curator of the collection since the 1980s.

Remarks: Xenofrea simplicioi sp. nov. is similar to $X$. murina Néouze \& Tavakilian, 2005 (see photographs at Bezark, 2020), but differs as follows: antennomeres III-XI unicolorous (bicolorous in $X$. murina); elytral apex nearly triangularly-shaped (more rounded in $X$. murina). The new species differs from $X$. arcifera Néouze \& Tavakilian, 2005 (see photographs at Bezark, 2020), by the antennomeres III-XI unicolorous (bicolorous in X. arcifera), protibiae without tooth at inner apex (present in $X$. arcifera), and by the different elytral pubescence pattern. It differs from X. obscura Galileo \& Martins, 2005 (see photographs at Bezark, 2020), by the different elytral pubescence pattern, and elytra with dorsal surface depressed on posterior half (lacking depression in X. obscura), and by the mesoventral process distinctly narrower than mesocoxal cavity (almost as wide as mesocoxal cavity in X. obscura).

Note: The width of the mesoventral process was not mentioned in the original description of $X$. obscura. However, the two female paratypes currently deposited at MZSP have the width distinctly different (but not as in Xenofrea simplicioi). This associated with some other differences suggests that the type series encompasses more than one species. It will be necessary to examine the holotype and all paratypes to clarify this problem.

\section{ACKNOWLEDGMENTS}

We express our sincere thanks to Prof. Dr. Marcelo Teixeira Tavares, curator of the UFES entomological collection; José Simplício dos Santos, former curator of the RNV collection; the SSA team for the availability of Cerambycidae specimens for identification; Dr. Prof. Sérgio Fiuza Ferreira, from the Federal University of Viçosa, for his collaboration and technical support in conducting knowledge research on Entomofauna in the state of Espírito Santo; to the Confederação da 
Agricultura e Pecuária do Brasil (CNA), Empresa Brasileira de Pesquisa Agropecuária (Embrapa), and Instituto Capixaba de Pesquisa Assistência Técnica e Extensão Rural (Incaper) for the financial support to the Biomes of Brazil/Atlantic Forest Biome Project (Subproject MA 25). The second author thanks the "Fundação de Amparo à Pesquisa do Estado de São Paulo" (FAPESP) for a postdoctoral fellowship (process number 2017/17898-0). The third author is grateful for the grant 2017/15283-9, São Paulo Research Foundation (FAPESP).

\section{AUTHOR'S CONTRIBUTIONS}

All authors contributed equally.

\section{REFERENCES}

Bezark, L.G. 2020. A photographic Catalog of the Cerambycidae of the World. New World Cerambycidae Catalog. Available at: http://bezbycids.com/ byciddb/wdefault.asp?w=n. Access in: 04/2020.

Bezark,L.G.\&Monné,M.A.2013.ChecklistoftheOxypeltidae, Vesperidae,Disteniidae and Cerambycidae (Coleoptera) of the Western Hemisphere. Available at: http://plant.cdfa.ca.gov/byciddb/checklists/WestHemiCerambycidae2013. pdf. Access in: 04/2020.

Brown, J.H. \& Gibson, A.C. 1983. Biogeography. London, C.V. Mosby Company. $643 p$.

Buquet, J.B.L. 1844. In: Guérin-Méneville, F.E. Iconographie du regne animal de G. Cuvier, ou représentation d'après nature de l'une des espèces les plus remarquables et souvent non enconre figurées, de chaque genre d'animaux (Insectes). Paris, J.B. Baillière. v. 7, 576p.

Chevrolat, L.A. 1862. Révision des genres Eriphus et Mallosoma Serville, du groupe des clytides et description de trois nouveaux genres dont un doit etre rapporté au groupe des callidiites. Annales de la Société Entomologique de France, Quatrième Série, 2: 747-763.

Didhamet, R.K.; Ghazoul, J.; Stork, N.E. \& Davis, A.J. 1996. Insects in fragmented forests: a functional approach. Trends in Ecology and Evolution, 11(6): 255-260.

Fragoso, S.A. 1970. Primeira nota preliminar a uma futura revisão dos Cerambycini neotropicais (Coleoptera, Cerambycidae). Atas da Sociedade de Biologia, 14(3-4): 97-101.

Fragoso, S.A. 1981. Third preliminary note on neotropical Cerambycini (Coleoptera). Revista Brasileira de Biologia, 41(2): 379-383.

Galileo, M.H.M. \& Martins, U.R. 2010. Novas espécies de Prioninae e de Cerambycinae (Cerambycidae) da região Neotropical. Revista Brasileira de Entomologia, 54(1): 32-37.

Garay, I.; Rizzini, C.M.; Kindel, A.; Agarez, F.V.; Louzada, M.A.P.; Santos, R.D. \& Vincens, R.S. 2004. Diversidade funcional da cobertura arbórea. In: Garay, I. \& Rizzini, C.M. (Orgs.). A floresta atlântica de tabuleiros: diversidade funcional da cobertura arbórea. Petrópolis, Vozes. p. 3-56.

Gounelle, E. 1911. Liste des cérambycides de la région de Jatahy, Etat de Goyaz, Brésil (2 partie). Annales de la SociétéEntomologique de France, 80: 1-150.

Grew, H. 1681. Musaeum Regalis Societatis. Or a catalogue \& description of the natural and artificial rarities belonging to the Royal Scociety anf preserved at Grefham Colledge. London, W. Rawlins. viii + 386p. + 43p. + 31 plates.

Gronovius, L.T. 1764. Zoophylacii Gronoviani. Fasciculus secundus. Exhibens enumerationem Insectorum, quae in Museo suo adservat, examini subjecit, systematice disposuit atque descripsit. Lugduni Batavorum, Gronovius, L.T. p. $141-236$ + errata.
Gronovius, L.T. 1781. Zoophylacii Gronoviani. Fasciculus tertius. Exhibens Vermes, mollusca, Testacea et Zoophyta, quae in Museo suo adservavit, examini subjecit, systematice disposuit atque descripsit. Lugduni Batavorum, Theodorum Haak and associate, and Samuelem and Johannen Luchtmans. iv + p. 241-380 + index + 1-6 (legend of plates) +20 plates.

Jesus, R.M. \& Rolim, S.G. 2005. Fitossociologia da Mata Atlântica de Tabuleiro. Boletim Técnico da Sociedade de Investigações Florestais, 19: 1-149.

Kierulff, M.C.M.; Avelar, L.H.S.; Ferreira, M.E.S.; Povoa, K.F. \& Bérnils, R.S. 2014. Reserva Natural Vale: história e aspectos físicos. Ciência \& Ambiente, 49: 7-40.

Linnaeus, C. 1758. Systema naturae per regne tria naturae secundum classes, ordines, genera, species, cum characteribus, differentiis, synonymis, locis. Holmiae, Salvius. v. 1, iii, 824p.

Linnaeus, C. 1767. Systema naturae. Editio duodecima reformata.. Holmiae, L. Salvius. v. 1, pt. 2, p. 533-1327.

Lucas, P.H. 1857. Entomologie. In: Animaux nouveaux ou rares recueillis pendant l'expédition dans les parties centrales de l'Amérique du Sud, de Rio de Janeiro a Lima, et de Lima au Pará, exécutée par ordre du Gouvernement Français pendant les années 1843 a 1847, sous la direction du Comte F. de Castelnau. Paris, Bertrand. 204p.

Martins, D.S.; Ferreira, P.S.F.; Fornazier, M.J. \& Santos, J.S. 2014. Insetos da Reserva Natural Vale, Linhares, Espírito Santo, Brasil. Ciência \& Ambiente, 49: 219-235.

Martins, D.S.; Ferreira, P.S.F.; Fornazier, M.J. \& Santos, J.S. 2016. Coleópteros e hemípteros da Reserva Natural Vale. In: Rolim, S.G.; Menezes, L.F.T. \& Srbek-Araujo, A.C. (Eds.). Floresta Atlântica de Tabuleiro: diversidade e endemismo na Reserva Natural Vale. Belo Horizonte, Editora Rona. p. 341-363.

Martins, U.R. 1980. Revisão dos gêneros Austroeme, Stenoeme, Xanthoeme, gen. n. e Ocroeme (Coleoptera, Cerambycidae). Papéis Avulsos de Zoologia, 33(11): 221-229.

Martins, U.R. 1997a. Contribuições para uma revisão das espécies sulamericanas da tribo Eburiini (Coleoptera, Cerambycidae). Revista Brasileira de Entomologia, 41(1): 57-83.

Martins, U.R. 1997b. Tribo 0emini. In: Martins, U.R. (Org.). Cerambycidae Sul-Americanos (Coleoptera). Taxonomia. Vol. 1. São Paulo, Sociedade Brasileira de Entomologia. p. 4-155.

Martins, U.R. \& Galileo, M.H.M. 1990. Onciderini (Coleoptera, Cerambycidae, Lamiinae): sinonímias, novos táxons, chaves e notas. Papéis Avulsos de Zoologia, 37(4): 53-95.

Martins, U.R. \& Galileo, M.H.M. 2010. Novos táxons em Onciderini (Coleoptera, (erambycidae, Lamiinae). Revista Brasileira de Entomologia, 54(1): 66-71.

Martins, U.R. \& Galileo, M.H.M. 2011. Subfamília Cerambycinae, Clytini Mulsant, 1839. In: Martins, U.R (Org.). Cerambycidae Sul-Americanos (Coleoptera) Taxonomia. Vol. 12. São Paulo, Sociedade Brasileira de Entomologia. 264p.

Menezes, E.C.; Silva-Neto, A.M.; Nascimento, F.E.L. \& Bravo, F.R. 2012. Lista dos Cerambycidae, incluindo 12 holótipos presentes no Museu de Zoologia da Universidade Estadual de Feira de Santana e o primeiro registro da espécie Chrysoprasis airi Napp \& Martins para o Brasil. EntomoBrasilis, 5(1): 49-58.

Merian, M.S. 1705. Metamorphosis insectorum surinamensium. Ofte verandering der Surinaamsche insecten. Waar in de Surinaamsche rupsen en wormen met alle des zelfs veranderingen na het leven afgebeeld en beschreeven worden, zynde elk geplaast op die gewassen, bloemen en vruchten, daar sy op gevonden zyn; waar in ookde generatie der kikvorschen, wonderbaare padden, hagedissen, slangen, spinnen en mieren warden ver toond en beschreeven, alles in America na het leven en 
levensgroote geschildert en beschreeven. Amsterdan, M.S. Merian \& Valck G. ii +60 p. +60 plates.

Monné, M.A. 1994a. Catalogue of the Cerambycidae (Coleoptera) of the Western Hemisphere. Part XI. Subfamily Cerambycinae: Tribes Torneutini, Trachyderini and Basipterini. São Paulo, Sociedade Brasileira de Entomologia. 157p.

Monné, M.A. 1994b. Catalogue of the Cerambycidae (Coleoptera) of the Western Hemisphere. Part XIV. Subfamily Lamiinae: Tribes Apomecynini, Agapanthiini and Onocephalini. São Paulo, Sociedade Brasileira de Entomologia. 72p.

Monné, M.A. 2020a. Catalogue of the Cerambycidae (Coleoptera) of the Neotropical region. Part I. Subfamily Cerambycinae. Available at: https:// cerambycids.com/catalog. Access in: 04/2020.

Monné, M.A. 2020b. Catalogue of the Cerambycidae (Coleoptera) of the Neotropical region. Part II. Subfamily Lamiinae. Available at: https:// cerambycids.com/catalog. Access in: 04/2020.

Monné, M.A. 2020c. Catalogue of the Cerambycidae (Coleoptera) of the Neotropical region. Part III. Subfamilies Lepturinae, Necydalinae, Parandrinae, Prioninae, Spondylidinae and Families Oxypeltidae, Vesperidae and Disteniidae. Available at: https://cerambycids.com/ catalog. Access in: 04/2020.

Monné, M.A. \& Fragoso, S.A. 1996. Sobre Eriphus Audinet-Serville, 1834 e Athetesis Bates, 1870 (Coleoptera, Cerambycidae, Cerambycinae, Trachyderini). Revista Brasileira de Entomologia, 40(1): 113-120.

Monné, M.A. \& Giesbert, E.F. 1992. Nomenclatural notes on Western Hemisphere Cerambycidae (Coleoptera). Insecta Mundi, 6(2): 249-255.

Monné, M.A. \& Giesbert, E.F. 1994. Checklist of the Cerambycidae and Disteniidae (Coleoptera) of the Western Hemisphere. Burbank, Wolfsgarden Books. 409p.

Morvan, 0. \& Morati, J. 2011. Inventaire des Cerambycidae (Coleoptera) de Guyane. I. Supplement au Bulletin de liaison d'ACOREP-France "Le Coléoptériste", 3: 10-45.

Peixoto, A.L.; Silva, I.M.; Pereira, 0.J.; Simonelli, M.; Jesus, R.M. \& Rolim, S.G. 2008. Tableland Forests North of the Rio Doce: their representation in the Linhares Forest Reserve, Espírito Santo State, Brazil. Memoirs of the New York Botanical Garden, 100: 369-372.
Perger, R.; Santos-Silva, A. \& Guerra, F. 2017. Description of the male of Phoebe ornator (Tippmann, 1960) (Coleoptera: Cerambycidae: Lamiinae: Hemilophini), analysis of the species biogeography, and first observation of chromatic gender dimorphism in Hemilophini. Zootaxa, 4250(4): 337-346.

Rösel, A.J. 1746. De natuurlyke historie der insecten; voorzien met naar't leven getekende en gekoleurde plaaten. Volgens eigen ondervinding beschreeven, door den heer August Johan Rösel, van Rosenhof, miniatuur-schilder. Met zeer nutte en fraaie aanmerkingen verrykt, door den heer C.F.C. Kleemann. Amsterdam, C.H. Bohn \& Gartman H. 2, part 1, x + 251p.

Sarmento-Soares, L.M. \& Martins-Pinheiro, R.F. 2014. A fauna de peixes na bacia do rio Barra Seca e na REBI0 de Sooretama, Espírito Santo, Brasil. Boletim do Museu de Biologia Prof. Mello Leitão, Nova Série, 35: 49-104.

Schmid, H. 2017. Ein neuer Bockkäfer aus Ecuador (Coleoptera, Cerambycidae). Koleopterologische Rundschau, 87: 289-291.

Tavakilian, G.; Berkov, A.; Meurer-Grimes, B. \& Mori, S. 1997. Neotropical tree species and their faunas of xylophagous longicorns (Coleoptera: (erambycidae) in French Guiana. The Botanical Review, 63(4): 303-398.

Travassos, L. \& Freitas, J.F.T. 1948. Relatório da excursão do Instituto Oswaldo Cruz ao norte do Estado do Espírito Santo, junto ao Parque de Reserva e Refúgio Soóretama, em fevereiro e março de 1948. Memórias do Instituto Oswaldo Cruz, 46(3): 605-631.

Viana, M.J. 1972. Aporte al catálogo de Cerambycidae del Paraguay (Insecta, Coleoptera). Revista del Museo Argentino de Ciencias Naturales Bernardino Rivadavia. Entomologia, 3(4): 207-405.

Vincent, L. 1699. Elenchus tabularum, pinacothecarum, atque nonnullorum cimeliorum, in gazophylacio Levini Vincent. Harlem, Vicent, L. xxii + 52p. +7 plates.

Zajciw, D. 1965. Contribuições para 0 estudo da fauna dos longicórneos do Estado da Paraíba (Coleoptera, Cerambycidae). Boletim da Sociedade Cearense de Agronomia, 6: 5-21.

Zajciw, D. 1974. Contribuição para 0 estudo da fauna dos longicórneos (Coleoptera, Cerambycidae) das florestas do Estado do Espírito Santo e principalmente da Reserva Biológica Soôretama. Boletim Técnico do Instituto Brasileiro de Desenvolvimento Florestal, 4: 37-91. 